\title{
The Location of Mount Masa on the Northern Border of Hellenistic Lycia
}

\author{
Fatih ONUR*
}

\section{Introduction}

for Denis Rousset

From 1993 onwards the name of Mount Masa was known from an inscription found in the Letoon. The inscription was published by D. Rousset in 2010, after a lengthy work on its contents. ${ }^{1}$ The inscription records a convention between the Lycian League and Termessos at Oinoanda, dated between 160 and 150 B.C., and is one of the most interesting recent epigraphic finds concerning ancient topography, as the text includes a long and detailed description of the demarcation work around Mount Masa. Mount Masa is also recorded in the foedus (treaty) between Caesar and Lycia in 46 B.C. as one of the landmarks on the northern border of Lycia. ${ }^{2}$ After Rousset (and after S. Vatin, who translated the text from French and general conclusions into Turkish in the same book on pp. 171-175), the late S. Şahin produced a Turkish translation of the text, presenting some revised readings of the Greek text and in understanding the descriptions. ${ }^{3}$ Neither Rousset nor the late S. Şahin nor our team (in 2015) were able to locate Mount Masa precisely in the Akdağlar mountain range. This paper will not focus on its historical background or legal aspects of the text, which have been extensively discussed by D. Rousset, but concerns the location of the demarcated area as a result of preliminary research carried out in 2019, based on study of regional maps and ground testing of our expectations through field surveys, which we believe that we have established the mountain's topography. We plan more comprehensive research in the near future.

\footnotetext{
* Prof. Dr. Fatih Onur, Akdeniz University, Faculty of Letters, Dept. of Ancient Languages and Cultures, Campus 07058 Antalya (fatihonur@akdeniz.edu.tr; https://orcid.org/0000-0002-8568-0222).

This contribution results from the field surveys on the ancient roads of Lycia directed by the author, with permission from the Turkish Ministry of Culture and Tourism. These field surveys have been supported by the Akdeniz University Scientific Research Projects Coordination Unit within the project no. SBA-2019-4823 conducted by M. Ertan Yıldız, and by Koç University - Suna \& İnan Kıraç Research Center for Mediterranean Civilizations from 2015 onwards (especially within the project no. KU AKMED 2018/P.1016). I am deeply grateful to Niyazi Alt1, our local friend, who lives in Makmara Yaylası and who escorted and guided us in this difficult area, and to M. E. Yıldız, F. Avcu, Y. Doğan, B. Karabulut, Y. E. K. Yılmaz and S. Özkadif for their effort in the difficult walks on this steep territory. I am particularly grateful to Denis Rousset, with whom I found the opportunity to discuss the issues addressed in this paper at the Kommission für Alte Geschichte und Epigraphik of DAI in Munich. I also thank N. E. Akyürek Şahin, T. M. P. Duggan, B. Ceylan Duggan, S. Mitchell and N. P. Milner for their valuable remarks in discussions leading to this contribution. This paper also forms a part of my project entitled "The spatial conceptualization of power in the Roman empire: Lycia and Rome in the $1^{\text {st }}$ c. A.D.", the funding of which has been provided by the Alexander von Humboldt Foundation.

${ }^{1}$ For preliminary reports see Le Roy 1996 and Le Roy - Rousset in: Courtils - Laroche 2003, 452-456; For full edition see Rousset 2010; SEG 60, 485-490, no. 1569; AE 2010, 644-645, no. 1644; BE 2011, 481483 , no. 554 .

${ }^{2}$ Mitchell 2005, 169 1. 58, 178 and for commentary see pp. 215-216; SEG 55, 1452; AE 2005, 514-520, no. 1487; BE 2006, 638-642, no. 143.

${ }^{3}$ Şahin 2014, 215-219.
} 
The text, which is based on Rousset's edition, and its English translation are as follow:

Topographical abbreviations: $\mathrm{Rv}=$ Ravine; $\mathrm{R}=$ Road; $\mathrm{B}=$ Boundary mark; $\mathrm{RG}=$ Golbanounda; $\mathrm{RE}=$ Endyrenos

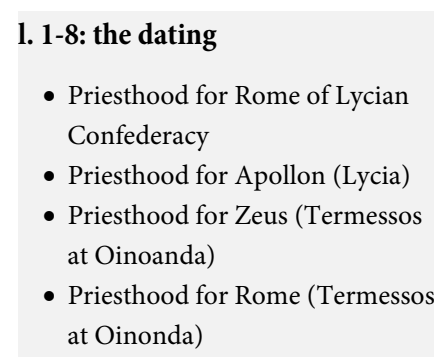

1.9-22: the signatory delegates of both parties

- Five men from Lycia (1 from Xanthos, 1 from Phellos, 1 from Kyaneai, 2 from Tlos)

- Seven men from Termessos at Oinoanda

1. 22-26: Termessans at Oinoanda consent to

- the decisions taken in Kos

- the transit rights concerning Tloans and Kadyandans

1. 27-33: The ownership and use of Mount Masa

- Tloans own the mount

- Termessans at Oinoanda benefit from it only for grazing and lumber

1. 33-91: The demarcation work of Mount Masa

1. 34-37: The southern ravine (Rv1) leading down from the mount and ending on the road between Tlos and

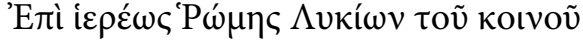

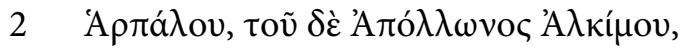

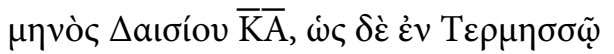

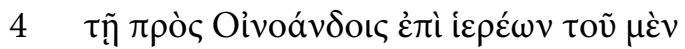

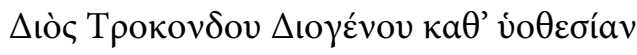

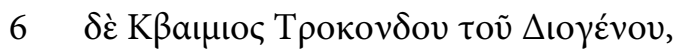

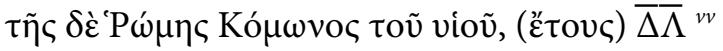

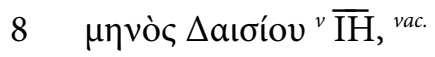

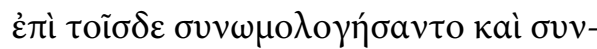

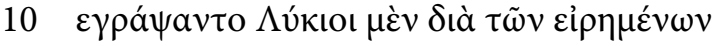

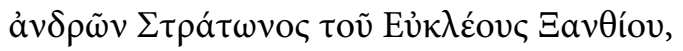

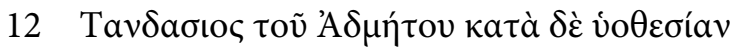

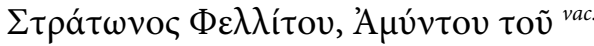

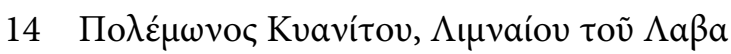

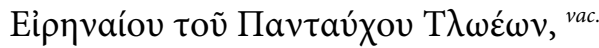

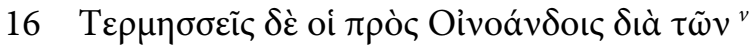

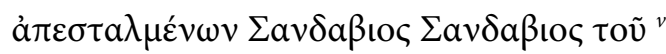

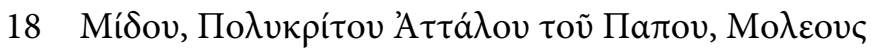

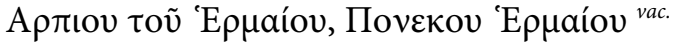

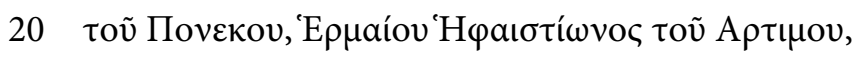

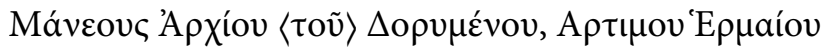

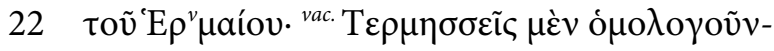

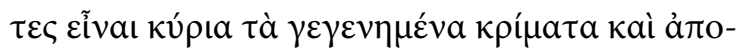

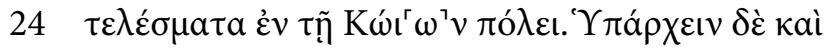

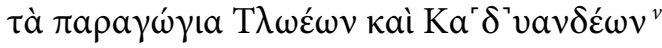

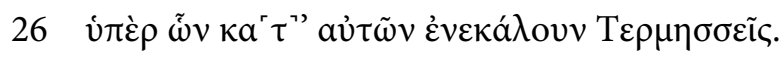

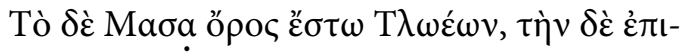

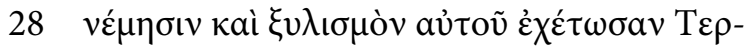

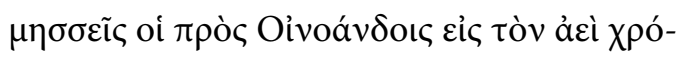

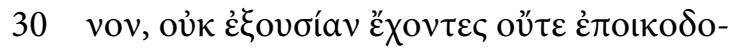

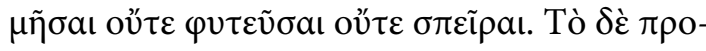

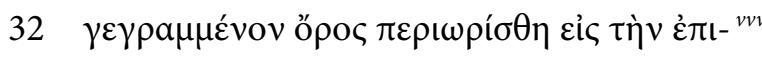

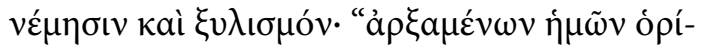

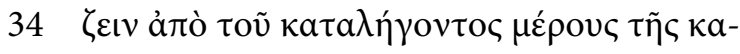

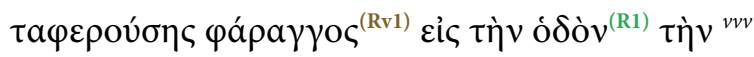

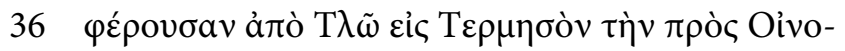


Termessos at Oinoanda; the first boundary mark.

1. 38-49, main road, second ravine (Rv2) and Golbanounda: The unmarked and descriptive part from the first boundary mark up to the ridgeway on the mountain; a considerably long section; The Golbanounda meets the ravine joining from the right (south), which reaches the ridgeway. The Wooden Hermaion in between was on the banks of the Golbanounda, while no hint for the location of "polyandreion".

1. 44: Şahin $\Gamma o \lambda \beta a v o v ' I v \delta \tilde{\omega} v$

1. 48: perhaps $\varepsilon ॉ \varsigma ~ \tau \varepsilon$

1. 49-56, the main junction: The meeting point of the Rv2 (west), ridgeway (north-south axis), the third ravine (Rv3; south) and River Endyrenos (east) is the most precise location in the text. On this very point, there is a rock, on which there should be a boundary mark.

1. 56-70, the third ravine (RV3): The surveyors start climbing up the ravine in a southerly direction. This is the first part of the main section, marked with 9 vertical boundaries. On its eastern slopes the ridgeway leads up. Here the ridgeway intersected with the borderline somewhere between B7 and B8. Both the ravine and the ridgeway reach the flatland, with the last vertical boundary mark (B10) in the ravine was carved.

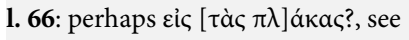
below p. 150 fn. 17.

1. 70: perhaps $[\ldots \pi \pi \lambda] a ́ k \alpha$ ?, see be low p. 150 fn. 17.

1. 70: Together with the next boundary mark, we see that horizontal marks on flat stones appear, indicating that the surveyors reached a plateau, "yayla”. See below p. 150 for a discussion on the beginnings of 1.66 and 1.70 .

1. 76-77: Şahin (2014, 218 fn. 408j) suggests that the distance here should

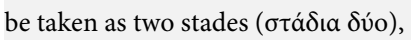
making the ending of $1.75 \ldots \Delta \mathrm{IA}$ and

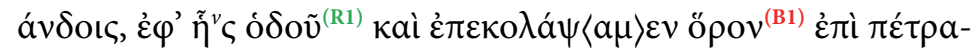

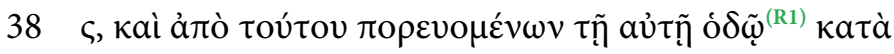

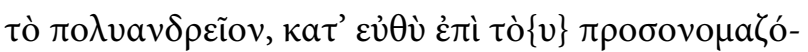

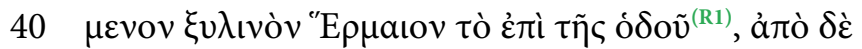

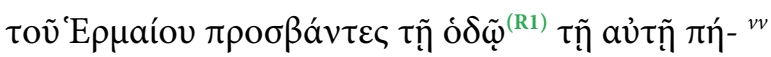

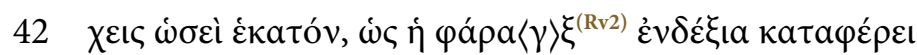

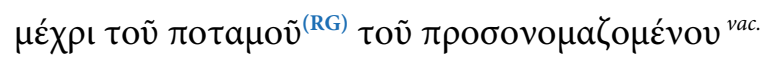

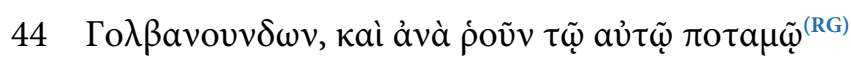

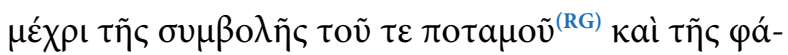

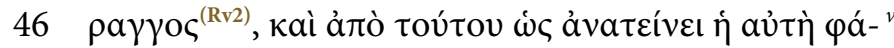

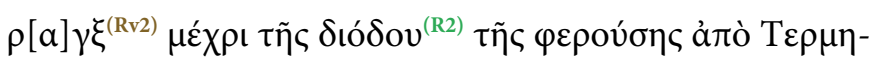

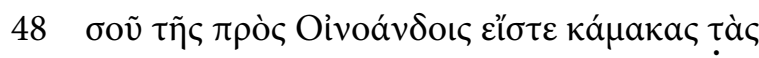

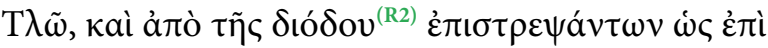

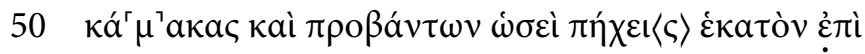

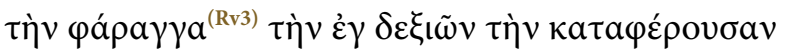

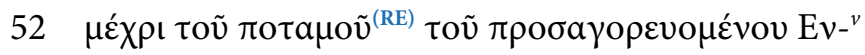

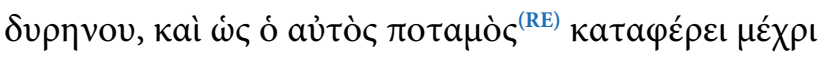

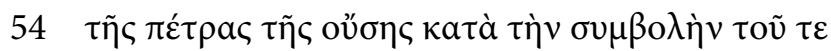

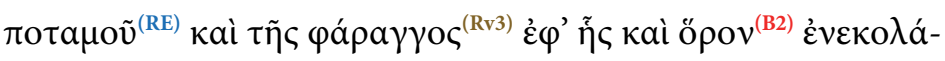

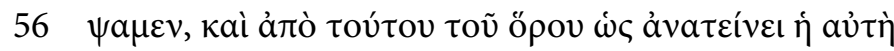

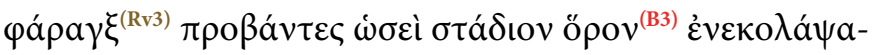

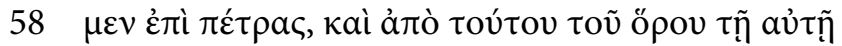

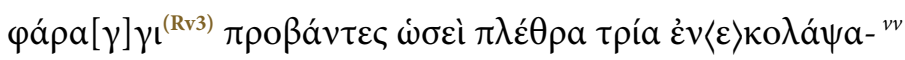

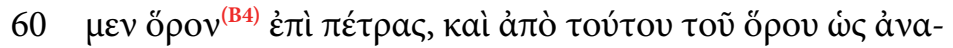

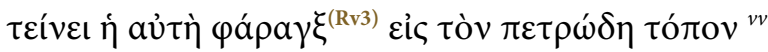

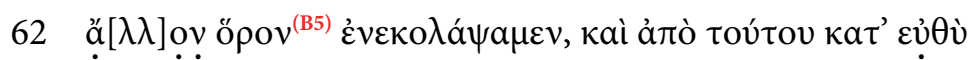

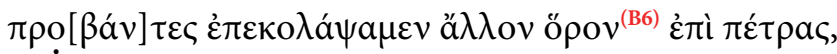

$64[\kappa a]$ [̇ [

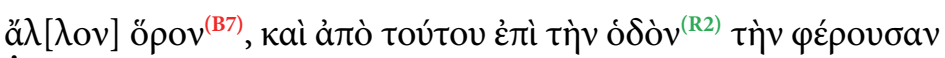

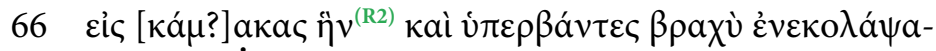

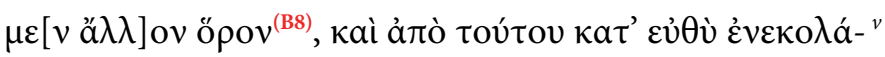

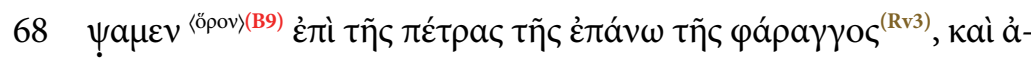

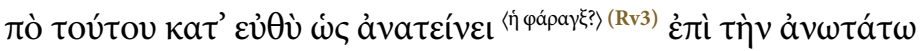

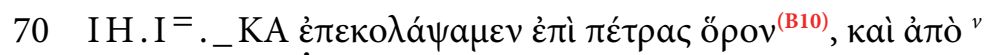

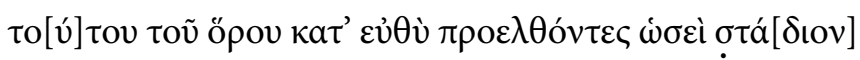

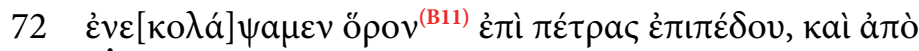

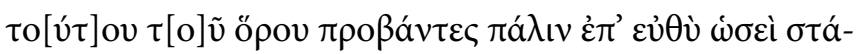

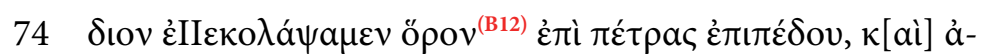


the beginning of $1.76 \Delta \mathrm{YO}$. But the end of 1.75 is clearly legible and $\Delta \mathrm{YO}$ does not make a sense in any circumstance. Rousset thought of the possibility of $\varepsilon \dot{v} \theta \varepsilon \dot{\varepsilon} \omega \varsigma$, but remained reluctant because of ' $\pi$ ' $\varepsilon \dot{v} \theta \dot{v}$ employed in previous line with the same meaning.

1. 84-91: The defile (aủxท́v) mentioned should have provided a pass to the peak of the mountain. The surveyors crossed over its mouth to the south, and carved last two boundary marks. No further boundary mark was carved beyond this point. A walk to the south took them to the top of the first ravine (Rv1).

1. 91-97: The cancellation of the Knidian arbitrage received from Roman Senate and the termination of the debate.

1. 97-104: Lycians pay 25 talent of new Rhodian silver plinthophors to the Termessans at Oinoanda; the penalty of 100 talents for a breach of agreement by one of the parties.

1. 104-110: Inscribing the treaty on four stone stelai to be erected in following places:

1. The Letoon of Xanthos

2. Tlos, the temple of Artemis

3. Termessos at Oinoanda, the temple of Zeus

4. Kaunos

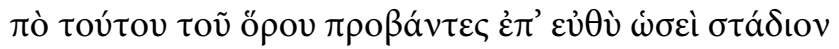

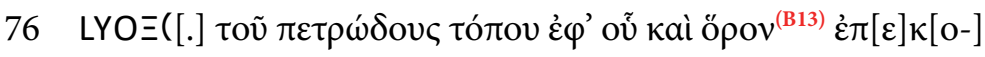

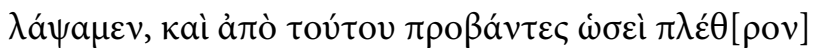

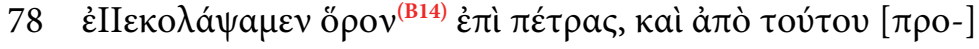

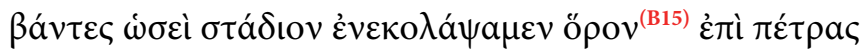

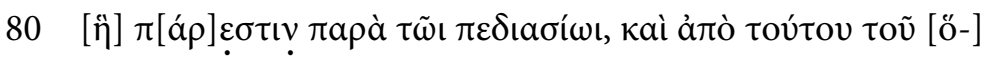

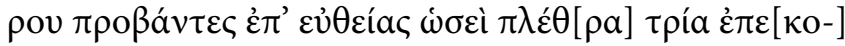

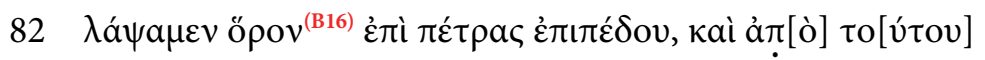

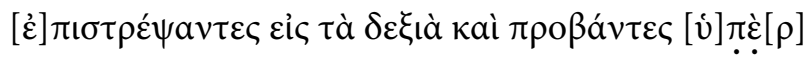

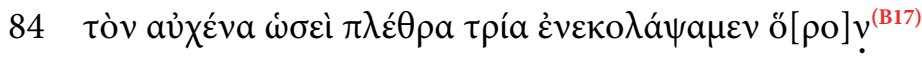

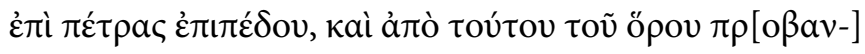

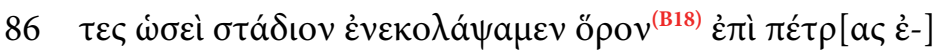

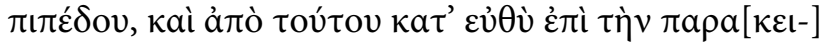

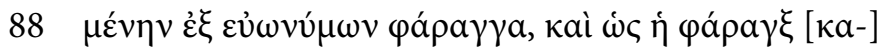

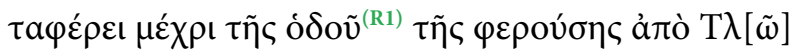

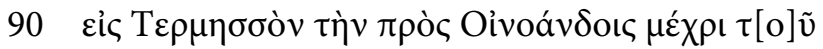

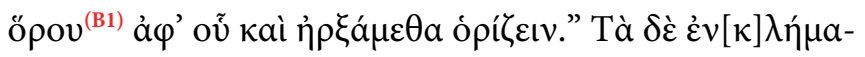

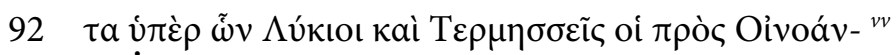

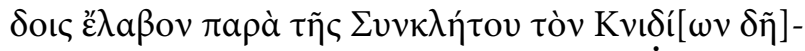

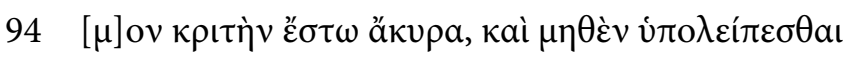

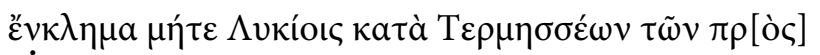

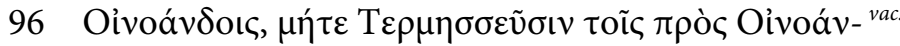

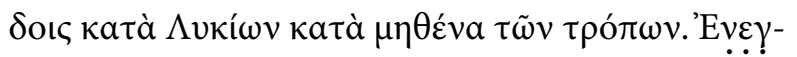

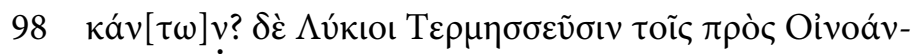

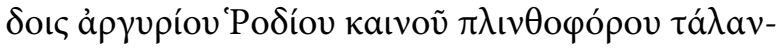

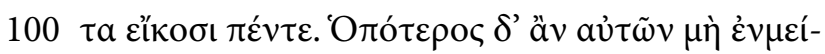

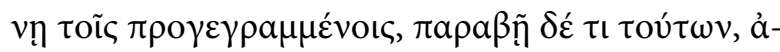

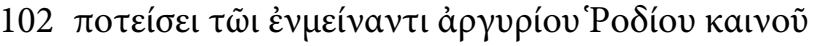

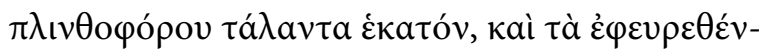

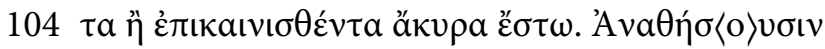

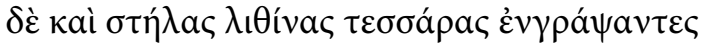

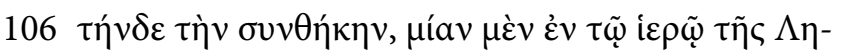

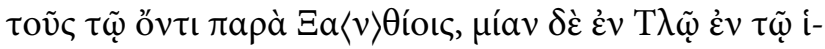

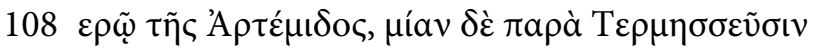

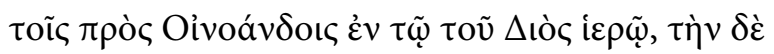

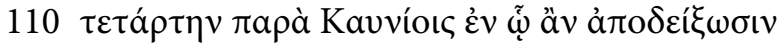

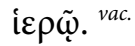
vac. 
[1.1-8] When Harpalos was priest for Rome of Lycian Confederacy and Alkimos for Apollon, in the $21^{\text {st }}$ of the month Daisios; while in Termessos at Oinoanda Trokondas (II), son of Diogenes (II) and adoptive son of Kibaimis of Trokondas (I) of Diogenes (I), was priest for Zeus, and Komon ${ }^{4}$, his (=Trokondas II) son, for Rome, in the $18^{\text {th }}$ of the month Daisios of $34^{\text {th }}$ year.

[1. 9-22] On one side the Lycians per the designated men: Straton from Xanthos, son of Eukles, Tandasis from Phellos, son of Admetos and adoptive son of Straton, Amyntas from Kyaneai, son of Polemon, Limnaios son of Labas and Eirenaios son of Pantakhos, both from Tlos; on the other side, Termessans at Oinoanda per the delegates Sandabis, son of Sandabis of Midas, Polykritos, son of Attalos of Papos, Moles, son of Arpias of Hermaios, Ponekos, son of Hermaios of Ponekos, Hermaios, son of Hephaistion of Artimas, Manes, son of Arkhias of Dorymenes, and Artimas, son of Hermaios of Hermaios, have together come to and drawn up the following terms:

[1.22-26] The Termessans conceding that the verdicts and enforcements brought in the city of Koans are valid, (and) that the transit rights concerning Tloans and Kadyandans, with which Termessans brought charges against them, already exist:

[1. 27-33] Let Mount Masa belong to Tloans, let the Termessans at Oinoanda have its rights of grazing and lumber evermore, without having the authority for building, sowing and harvesting. The mountain mentioned above has been demarcated for grazing and lumber:

[1.33-91] Starting the demarcating from the ending part of the ravine ${ }^{(\mathrm{Rv1})}$, which slopes down to the road ${ }^{(\mathrm{R} 1)}$ leading from Tlos to Termessos at Oinoanda, then on this road ${ }^{(\mathrm{R} 1)}$ we carved a boundary mark ${ }^{(\mathrm{B} 1)}$ on a rock; and from this ${ }^{\text {(boundary }}$ ${ }^{\text {mark) }}$ moving along the same road ${ }^{(\mathrm{R} 1)}$ down to the common burial-place, then straight to the so-called "Wooden Hermaion" on the road ${ }^{(\mathrm{RI})}$; then from the Hermaion walking about a hundred cubits ${ }^{(\mathrm{ca} .45 \mathrm{~m})}$ along the same road ${ }^{(\mathrm{R} 1)}$, as the ravine ${ }^{(\mathrm{Rv} 2)}$ on the right slopes down to the stream called Golbanounda ${ }^{6}$, and upward on the bed of the same stream ${ }^{(\mathrm{RG})}$ until the junction of the stream $^{(\mathrm{RG})}$ and the ravine ${ }^{(\mathrm{Rv} 2)}$; and from here, as the same ravine ${ }^{(\mathrm{Rv} 2)}$ slopes up to the pass ${ }^{(\mathrm{R} 2)}$, which leads from Termessos at Oinoanda to the stakes of Tlos, and from the pass ${ }^{(\mathrm{R} 2)}$, turning towards as if towards the stakes, and proceeding about hundred cubits $^{(\mathrm{ca} .45 \mathrm{~m})}$ to the ravine ${ }^{(\mathrm{Rv} 3)}$ on the right, which slopes down to the stream called Endyrenos, and as the same stream ${ }^{(\mathrm{RE})}$ runs down until the rock, which is

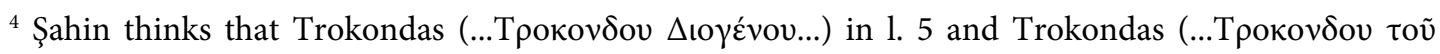
$\Delta$ toүévov...) in 1.6 were the same persons, and that Komon was the son of this Trokondas and adoptive son of Kibaimis, see Şahin 2014, 216 with fn. 408 b.

${ }^{5}$ Şahin suggests that $\pi 0 \lambda v a v \delta \rho \varepsilon i o v$ might refer to a common burial place for those who died in the same place after a war, as was already suggested by Rousset $(2010,56)$. He also also speculated whether the word was correctly inscribed, and suggested as an alternative $\pi 0 \lambda \nu \delta \varepsilon \dot{v} \delta \rho \varepsilon o v$, 'place of many trees, related to the woody nature of the place, and connected to the notion of a "Wooden Hermaion" (Şahin 2014, 216-217, fn. 408e). The word $\pi$ o $\lambda v a v \delta \rho \varepsilon i o v$ can clearly be read in the inscription.

${ }^{6}$ Şahin 2014, $217 \mathrm{fn}$. 408f suggests that reading should be corrected to $\Gamma \circ \lambda \beta a v o v ' I v \delta \tilde{\omega} v$, which he relates to the Indos River (Dalaman Çayı), the spring sources of which reach to Kabalia. But this proposal cannot be justified by both the reading and the geography.
} 
situated below the junction of the stream ${ }^{(\mathrm{RE})}$ and the ravine ${ }^{(\mathrm{Rv} 3)}$, and on which we carved a boundary mark ${ }^{(\mathrm{B} 2)}$, and from this boundary mark, as the same ra$v_{i n e^{(\mathrm{Rv} 3)}}$ climbs up, proceeding about a stade (ca. $\left.185 \mathrm{~m}\right)$ we carved a boundary mark ${ }^{(\mathrm{B})}$ on a rock, and from this boundary mark proceeding about three plethra ${ }^{(\mathrm{ca} .93 \mathrm{~m})}$ with the same ravine ${ }^{(\mathrm{Rv} 3)}$, we carved a boundary mark ${ }^{(\mathrm{B} 4)}$ on a rock, and from this boundary mark, as the same ravine ${ }^{(\mathrm{Rv} 3)}$ climbs up to the stony place, we carved another boundary mark ${ }^{(\mathrm{B} 5)}$, and from this ${ }^{\text {(boundary mark) }}$ proceeding straight we carved another boundary mark ${ }^{(\mathrm{B} 6)}$ on a rock, and slightly inclining to the right we carved another boundary mark ${ }^{(\mathrm{B} 7)}$, and from this ${ }^{(b o u n d a r y ~ m a r k)}$ towards the road ${ }^{(\mathrm{R} 2)}$ leading to stakes? (or to plateaux?) and stepping over it (=the road; R2) shortly we carved another boundary mark ${ }^{(\mathrm{B} 8)}$, and from this (boundary mark, walking) straight we carved a boundary mark ${ }^{(\mathrm{Bg})}$ on the rock on the upper part of the ravine ${ }^{(\mathrm{Rv} 3)}$, and from this ${ }^{(b o u n d a r y m a r k)}$ straight, as $<$ the ravine?> ${ }^{(\mathrm{Rv} 3)}$ reaches up to the topmost level ..., we carved a boundary mark ${ }^{(\mathrm{B} 10)}$ on a rock, and from this boundary mark going forward about a stade (ca. $185 \mathrm{~m})$ we carved a boundary mark ${ }^{(B 11)}$ on a flat rock, and from this boundary mark proceeding again straight about a stade ${ }^{(\mathrm{ca} .185 \mathrm{~m})}$ we carved a boundary mark ${ }^{(\mathrm{B} 12)}$ on a flat rock, and from this boundary mark proceeding right ahead about a stade (ca. $185 \mathrm{~m})$ leading straight to the stony place, on which we carved a boundary mark ${ }^{(\mathrm{B} 13)}$, and from this (boundary mark) proceeding about a plethron (ca. $31 \mathrm{~m}$ ) we carved a boundary mark ${ }^{(\mathrm{B} 14)}$ on a rock, and from this boundary mark proceeding about a stade (ca. $185 \mathrm{~m})$ we carved a boundary mark ${ }^{(\mathrm{B} 15)}$ on a flat rock, which is next to the plain, and from this boundary mark proceeding straight about three plethra ${ }^{\text {(ca. } 93 \mathrm{~m})}$ we carved a boundary mark ${ }^{(\mathrm{B} 16)}$ on a flat rock, and from this (boundary mark), turning right and proceeding about three plethra ${ }^{(\text {ca. } 93 \mathrm{~m})}$ across the defile we carved a boundary mark ${ }^{(B 17)}$ on a flat rock, and from this boundary mark proceeding about a stade (ca. $185 \mathrm{~m})$ we carved a boundary mark ${ }^{(\mathrm{B} 18)}$ on a flat rock, and from this ${ }^{\text {(boundary mark) }}$ straight up to the ravine ${ }^{(\mathrm{Rvl})}$ lying by left hand side (southerly), and as the ravine slopes down to the road ${ }^{(\mathrm{R} 1)}$ leading from Tlos to Termessos at Oinoanda until to the boundary mark ${ }^{(\mathrm{B} 1)}$, from which we started to demarcate.

[1. 91-97] Let the complaints, about which the Lycians and the Termessans at Oinoanda received from the Senate the people of Knidians as the judge, be invalid, in order that no complaint shall remain for the Lycians against the Termessans at Oinoanda, and for the Termessans at Oinoanda against the Lycians by no manner of means.

[1. 97-104] Let the Lycians bring in twenty-five talents of new Rhodian silver plinthophors to the Termessans at Oinoanda. In case one of them does not abide in what have been written above, and infringe one of them, it shall pay hundred talents of new Rhodian silver plinthophors to the abiding one, and let the supplements or revisions be invalid.

[1. 104-110] They shall set up four stone stelai, inscribing this convention: one in the sanctuary of Leto located beside the Xanthians, one at Tlos in the sanctuary of Artemis, one in the sanctuary of Zeus beside the Termessans at Oinoanda, fourth one beside Kaunians in a sanctuary they would assign. 
Both Rousset and Şahin presented hypothetical maps of the possible geographical situation based upon the description provided in the inscription (Fig. 1 and Fig. 2). They have understood some sections differently from each other, but both drawings are perfect examples of how people who are unfamiliar with the area, or just don't know where the mountain is, envisage the topography only from a textual description. Both drawings will surprise readers when compared to the mountain's actual geography.

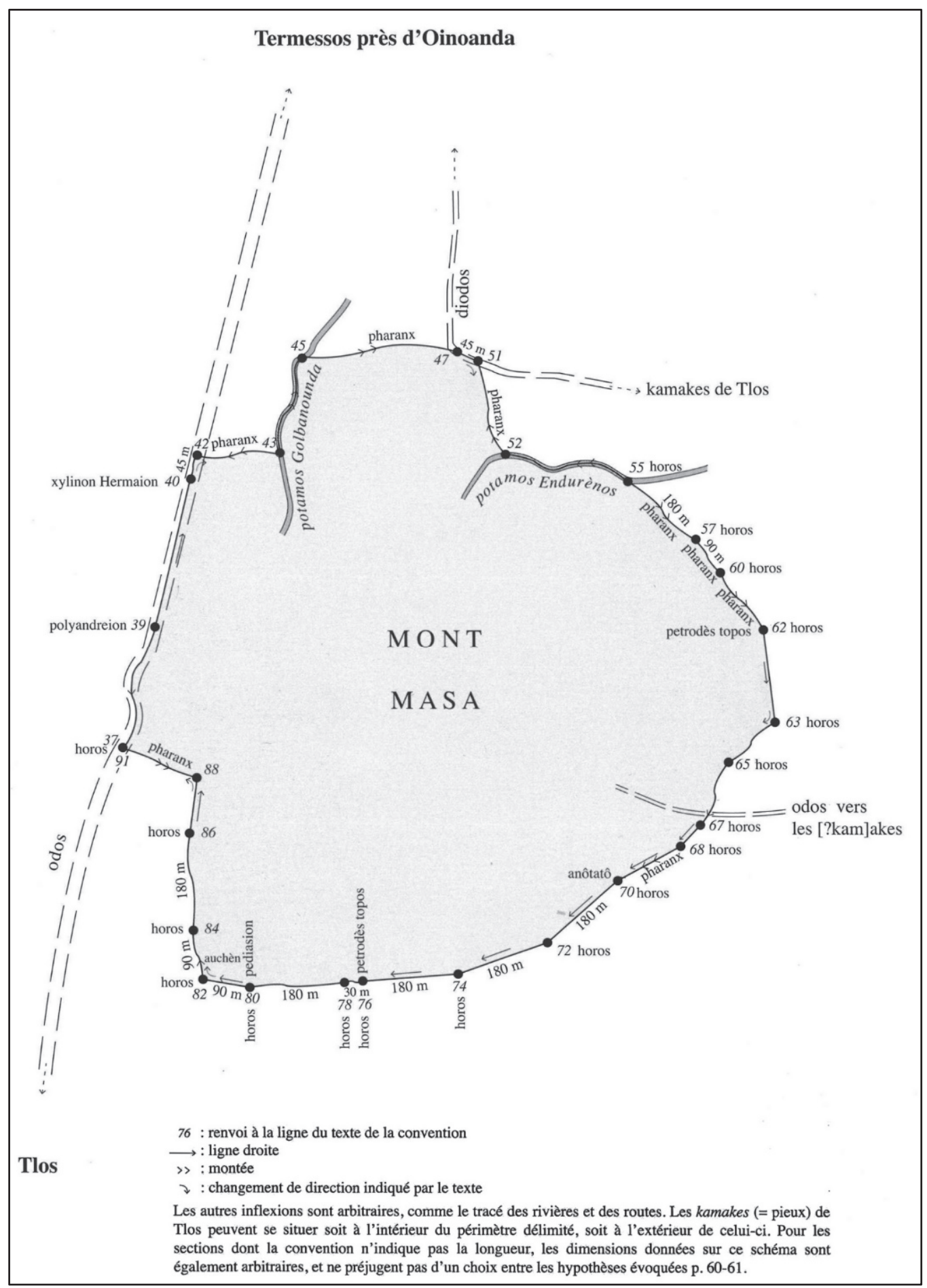

Fig. 1) Rousset's drawing (Rousset 2010, Fig. 42) 


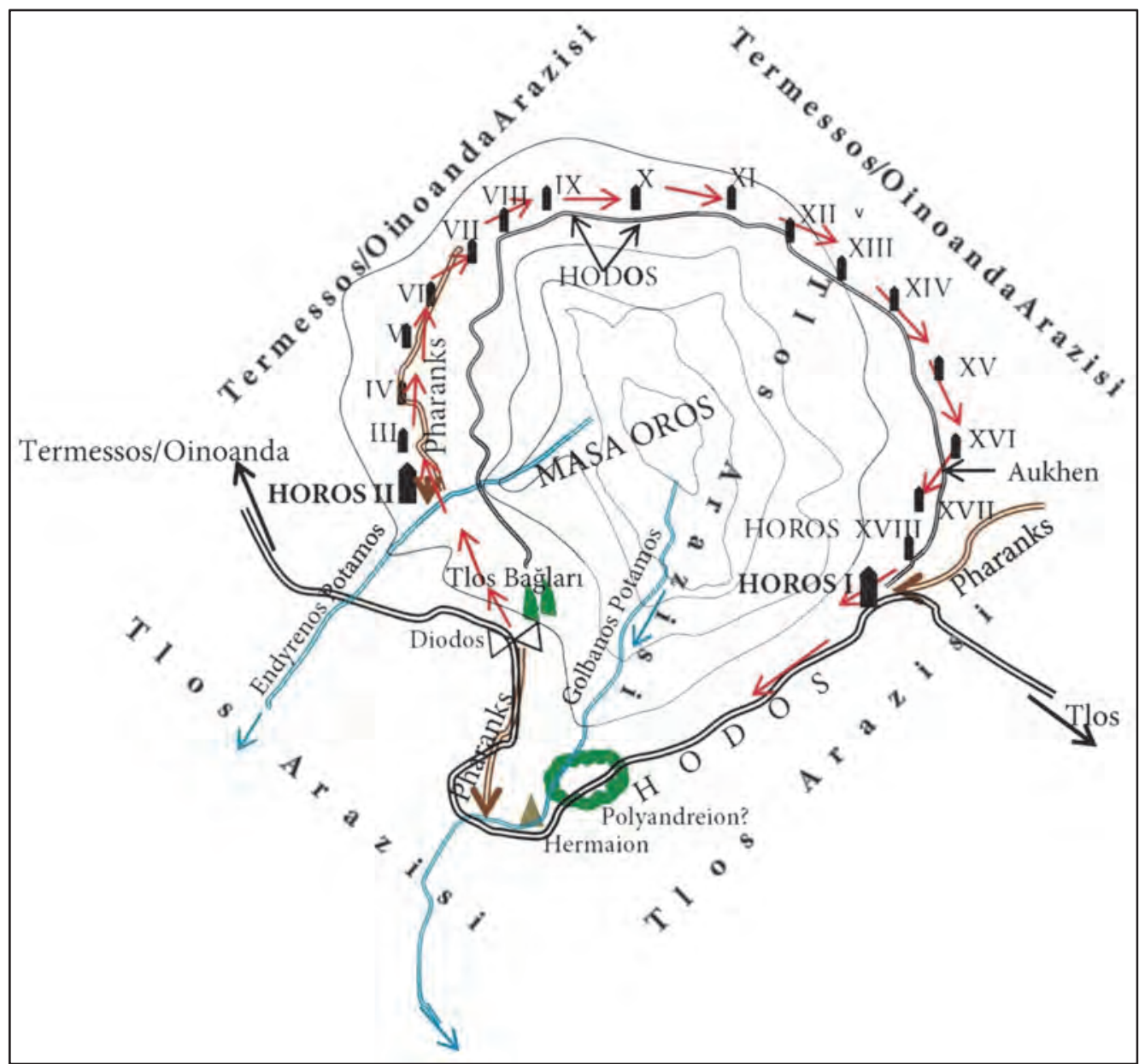

Fig. 2) Şahin's drawing (Şahin 2014, 219). "arazi” $\rightarrow$ "territory”; "Tlos Bağları" $\rightarrow$ "the vineyards of Tlos"

\section{General observations on the geography and on the topographical description given in the text}

Since the main road between Tlos and Termessos lay along a south-north axis, the first important topographical clue is that Mount Masa was isolated from the rest of the mountain range by two ravines, which cannot be confused with the others: one in the south, Rv1 (1. 33-37 and 1. 88-91), and one in the north (1. 42-49), Rv2, both of which should join or cross the main road between Tlos and Termessos and lead up to the mountain according to the description (see Fig. 1-Fig. 2 above). Namely, these ravines should have run without interruption between the road and the high mountain crests. The text implies that the northern ravine crosses the road and continues down the western slopes of the Mount Masa. Therefore, determining the course of the main road is very important for establishing the unmarked boundary of Mount Masa. We also understand that two rivers joined into the northern ravine. The river called Golbanounda (RG) flowed by "Wooden Hermaion" in the lower section of the ravine (1. 40-44), while the river called Endyrenos (RE) joined it in the upper sections of the same ravine, where it extended up to the pass/ridgeway (1. 46-49). These are basic elements which define the area.

Another point about the description in the text concerns the movement of the surveyors in the area. Our field surveys have shown that the surveyors did not walk along the entire boundary line that the inscription describes, since some sections were obviously impassable due to the very high rocky cliffs in the gullies and to the steep slopes, as we experienced ourselves in the northern 
ravine. There was no need to walk at all in these sections, as the ravines themselves sufficed to define the boundary, and a description alone was sufficient. These sections are indicated in the text by employing $\dot{\omega} \varsigma$. This word is used in 1.42 to describe a short section between the lower part of the Golbanounda on the road until the point where second ravine (Rv2) joins it higher up; 1.46 describes a slightly longer section from the junction of the Golbanounda and the northern ravine leading up to the ridgeway; 1.53 describes the course of the Endyrenos down to the rock where it meets the third ravine (Rv3); lines 56, 60 and 69 describe the ascent of the third ravine (Rv3); and 1. 88 describes the southern ravine (Rv1) sloping down to the road between Tlos and Termessos, where the demarcation started. The sections they walked or journeyed are indicated by phrases

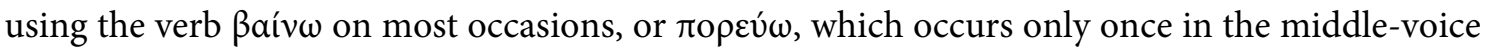
in 1. 38, and which should describe a different sort of movement from $\beta a i v \omega$. In 1. 38-40, where

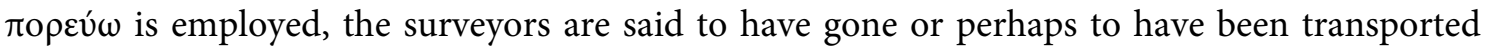
(mounted, or in a vehicle) from the first boundary mark to the common burial-place and the "Wooden Hermaion". Here they start to describe the boundary line formed by the northern ravine (Rv2). Hence, the section between the first boundary mark and the "Wooden Hermaion" seems to be the longest unmarked section of the entire boundary ${ }^{7}$. In any case, it seems to have been unnecessary to walk this section and to carve boundary marks, since the boundary here was formed by the road itself and the northern ravine. The surveyors certainly walked the section from the second to the eighteenth boundary mark. After the pass and the second boundary mark, the direction of demarcation shifted to the right, namely to the south. All the boundary marks were carved in sequence in this section until it passed over a defile, which is actually a pass to the peak of Mount Masa. This section with boundary marks was contiguous with the territory of Termessos, where the Termessans could enter the area along the mountainous ridgeway starting from the pass (diodos) leading to the Tloan "poles/stakes" and to the plateaux. The demarcation line continued from nearby the defile without marking boundaries up to the top of the southern ravine (Rv1), through which the boundary line descended to the first boundary mark. These descriptions do not enclose and demarcate a fixed $\operatorname{area}^{8}$, since only a small part of the boundary was defined with boundary marks, while the rest was established by main road and the ravines. A detailed study of maps and the use of 3D mapping software provided a good solution for the location of the Mount Masa, and this localization was supported by the field surveys of 2019. These discoveries also improve our understanding of some sections of the text.

In modern geography, the general name of the main mountain range between Tlos and Termessos/Oinoanda is Akdağlar. The part north of Tezli Dere is also called Küçük ("Minor") Akdağlar. There are also different names for separate parts of the range. The road from Tlos to Köristan leads quite straight through the western lower slopes of the Akdağ massif. Accordingly, Mount Masa should have been further north, somewhere between the southern flank of Tezli Dere and a point close to Oinoanda, namely on Küçük Akdağlar. The northern ends of the mountainous country to the north of Tezli Dere are relatively close to the city. From northwest to southeast the hills and mountains around Tezli Dere are:

\footnotetext{
${ }^{7}$ Cf. Şahin 2014, 218.

${ }^{8}$ Rousset 2010, 121 considers Mount Masa a small part of Akdağlar, see also 126: "entre 90 et 900 hectares".
} 
Table 1) The mountains and hills south and the north of Tezli Dere

\begin{tabular}{|c|c|c|c|c|c|}
\hline The south of Tezli Dere & Elevation & $\begin{array}{l}\text { Acreage } \\
\text { (approx.) }\end{array}$ & The north of Tezli Dere & Elevation & $\begin{array}{r}\text { Acreage } \\
\text { (approx. }\end{array}$ \\
\hline Dikmen Tepe (Karadağ) & $1300 \mathrm{~m}$ & 70 ha & Haciosman Dağ & $2440 \mathrm{~m}$ & 3300 ha \\
\hline Eren Tepe (Ulualan) & $2053 \mathrm{~m}$ & 570 ha & Bozkaya Tepesi & $2143 \mathrm{~m}$ & 710 ha \\
\hline Keklicek Tepe & $2099 \mathrm{~m}$ & 750 ha & Peynirdeliği Tepesi & $2050 \mathrm{~m}$ & 600 ha \\
\hline Yellidoru Tepesi & $2519 \mathrm{~m}$ & 540 ha & & & \\
\hline
\end{tabular}

There are other mountains in the direction of Oinoanda and Girdev, northeast of Tlos, but these are too far from the main road for them to be connected with the expected topography. Some of the mountains listed above can also be eliminated. Yellidoru Tepesi and Peynirdeliği Tepesi are too far east of the main road. However, the other mountains may have been accessible from the main ancient road from Tlos to Oinoanda. Mitchell proposed that it should be identified somewhere in the section between the south of Oinoanda and the west of Girdev. ${ }^{9}$ Rousset suggests in his maps that the eastern parts of Keklicek Tepe near Darı̈̈zü-Deliktaş (Kastabara) might have been Mount Masa ${ }^{10}$, while Şahin does not make any proposal.

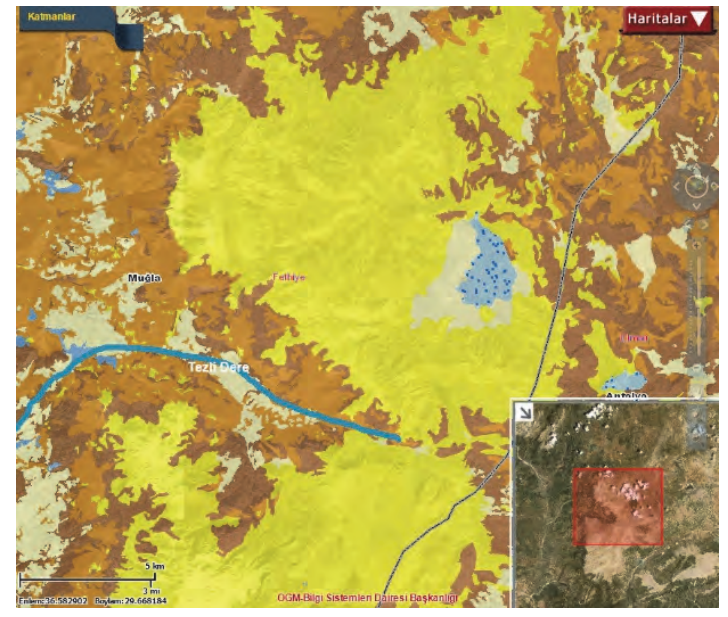

Fig. 3) Forest lands around Tezli Dere Yellow: non-forested; Brown: degraded forest lands Base Map: Turkish General Directorate of Forestry link: https://www.ogm.gov.tr/Sayfalar/OrmanHaritasi.aspx

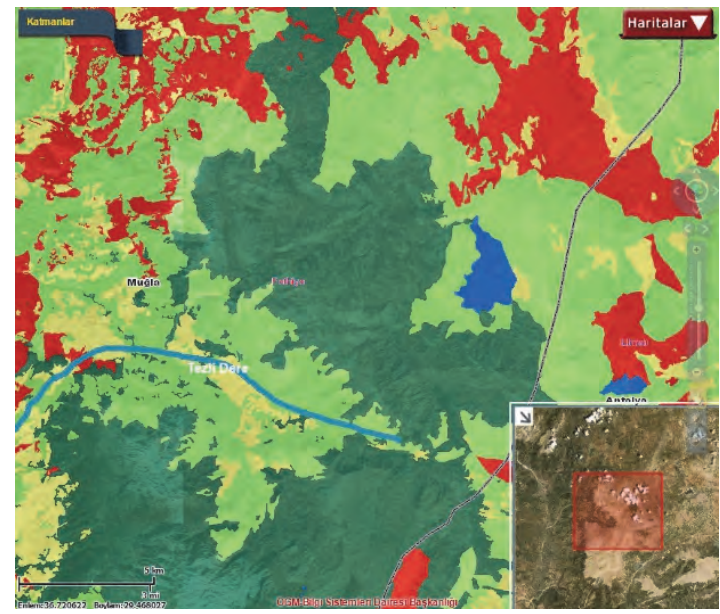

Fig. 4) Grazing areas around Tezli Dere Dark Green: primary lands; Light Green: free lands Base Map: Turkish General Directorate of Forestry link: https://www.ogm.gov.tr/Sayfalar/OrmanHaritasi.aspx

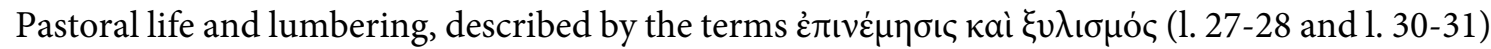
in the text, are still practised on the mountain plateaux, though they have become less important and most of the forests have become degraded today, as is the case, though better, for building,

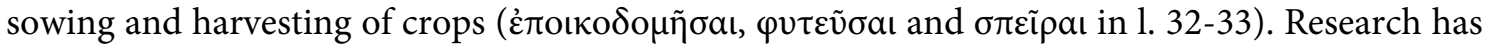
shown that the plateaux to the north of Tezli Dere, i.e. Küçük Akdağlar, are more fertile both for grazing and agriculture. ${ }^{11}$

\footnotetext{
${ }^{9}$ Mitchell 2005, 215-216 (the author inadvertently employed “east” of Girdev, cf. Rousset 2010, 123).

${ }^{10}$ Rousset 2010, figs. 41, 43.

${ }^{11}$ Güner - Ertürk 2005, 154-159.
} 


\section{Relevant remains concerning the roads between Tlos and Termessos/Oinoanda}

There are two roads mentioned in the text. One is the main road (R1; 1. 35-42 and 1. 88-91), the other is a ridgeway crossing over the mountains leading from Termessos to the "Tloan stakes" (R2; 1. 46-50 and 1.65-67). According to the text, the starting point of the demarcation is the end of a ravine, that leads down to the road between Tlos and Termessos. This is the main road leading past the western slopes of Mount Masa, while the ridgeway remains behind its peak to the east.

\section{The main road}

Detailed accounts of this road, mostly on its southern section, have already been given in other studies. ${ }^{12}$ Here I will summarize former conclusions and add the latest results from 2019 campaign, which provided important evidence concerning the road and the topography described in

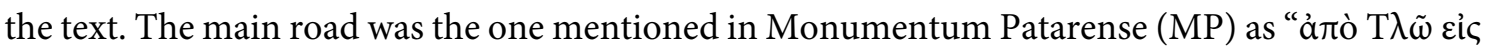

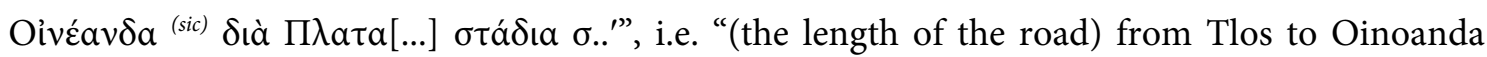
through (the territory) of Plata[...] (is) 2[..] stades". The distance between these two cities is at least 200 stades (ca. $37 \mathrm{~km}$ ), since the last one or two digits are lost. According to our observations, the length of the possible route was probably more than $40 \mathrm{~km}$. The settlement of Plata[...] mentioned between Tlos and Oinoanda has not been localised, but it was probably around Eren Tepe (Ulualan); and the ancient ruins in Zindan, Köristan, Dikmen Tepe, Çökek may have belonged to Plata[...], ${ }^{13}$ although none of the inscriptions found in these places mentions a toponym. ${ }^{14}$ The ancient route seems to have been followed by the modern road which leads through Yakaköy, Kayacık and Sögüt ${ }^{15}$. To the east of Köristan, on the western slope of Eren Tepe (Ulualan), we have found letters carved on the rocks (Fig. 5-Fig. 6). These were probably numbers, $5(\mathrm{E}), 6(\mathrm{~F})$ ?, $7(\mathrm{Z})$, perhaps encircling an area for a special purpose. ${ }^{16}$ But these marks cannot be related to the demarcation of Mount Masa as described in the text of the inscription.

After Köristan the road leads east into the valley of Tezli Dere, crosses the Tezli stream at the end of the Karabağlık ravine near Boyalı, and reaches Çökek, where there are several ancient tombs. We propose that the southern ravine mentioned in the text was the Karabağlik ravine, as this is the only ravine along the whole course of the road, which leads down from the mountain to the ancient road and ends there. The road should have passed east of Kayaarasi, where there are significant remains of an outpost on a hill. This outpost overlooks the Xanthian Valley to the west

\footnotetext{
${ }^{12}$ Akyürek Şahin et al. 2017a, 391-394; Akyürek Şahin et al. 2017b, 203-206; Onur 2017, 289-290.

${ }^{13}$ For the options of Köristan, Dikmen Tepe and Çökek to localize Plata[...] see Şahin - Adak 2007, 177 179; Şahin 2014, 212-215; Onur 2016, 92; for the archaeological remains in these places see Yılmaz - Çevik 1996, 192-193; Courtils - Laroche 2003, 454-456; Korkut 2014, 506-510; Korkut 2015a, 176-188; Çevik 2015, 260; Korkut 2015b, 55-58 and 129-132 res. 158-167; For Zindan see Yilmaz - Çevik 1996, 191-192; Courtils - Laroche 2003, 454; Korkut 2014, 511-514; Korkut 2015a, 188-197; Korkut 2015b, 58-61 and 133 135 res. 170-177; For the proposal of Zindan together with Köristan and Dikmen as Plata[...] see Onur 2017, 288-289.

${ }^{14}$ TAM II 2, nr. 712-717; Rousset 2010, 155-166 (Çökek).

${ }^{15}$ A part of the northern ancient road leaving Tlos was found by the team headed by T. Korkut, see Korkut 2015a, 118-120; Korkut 2015b, 39 and 108 res. 93.

${ }^{16}$ Onur 2017, 290, 298-299 figs. 2-5.
} 
and the road to the east, and was probably within the territory of Tlos. The Deliktaş ravine, which is north of the outpost, marked the boundary with Termessos (see below).

The northern section of the road cannot be traced until a clearly visible section on steep slopes to the north of Haciosman stream (Fig. 11-Fig. 13). The width of the road reaches up to $3 \mathrm{~m}$, and can be followed in two sections one for ca. $500 \mathrm{~m}$ on the south-eastern slopes of Eren Tepe below the Hac1osman fountain, another for ca. 150-200 m further up nearby the sources of the Hac1osman stream. The road ran to today's Çukuryurt, most probably passing by the eastern slope of Kızılca Tepe, and the western slopes of Nohutlu Tepe, finally reaching Kurttaşı through Çukuryurt. After Kurttaşı, Oinoanda is reached by a direct course along the ridge of Susuzdağ.

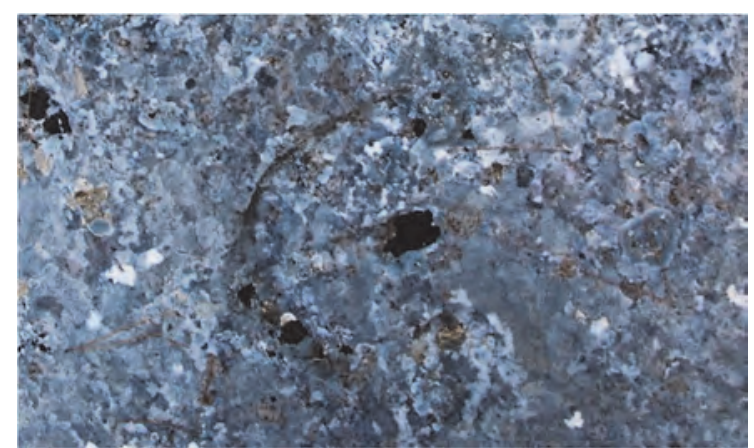

Fig. 5) Köristan. The letter E

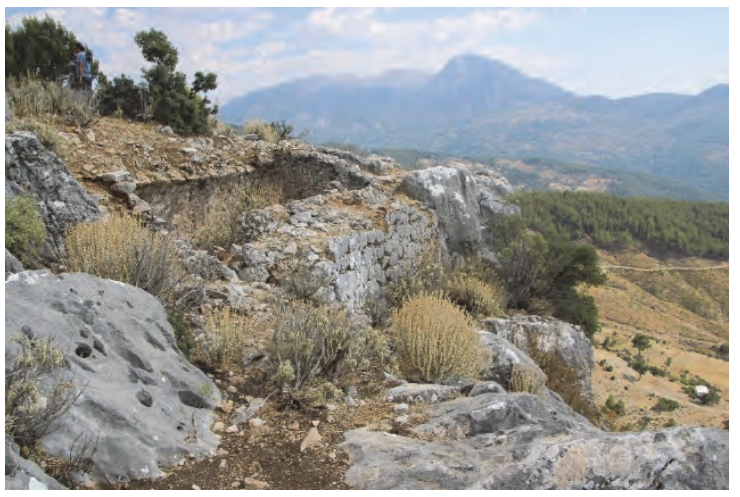

Fig. 7) Kayaarası. The remains of an outpost

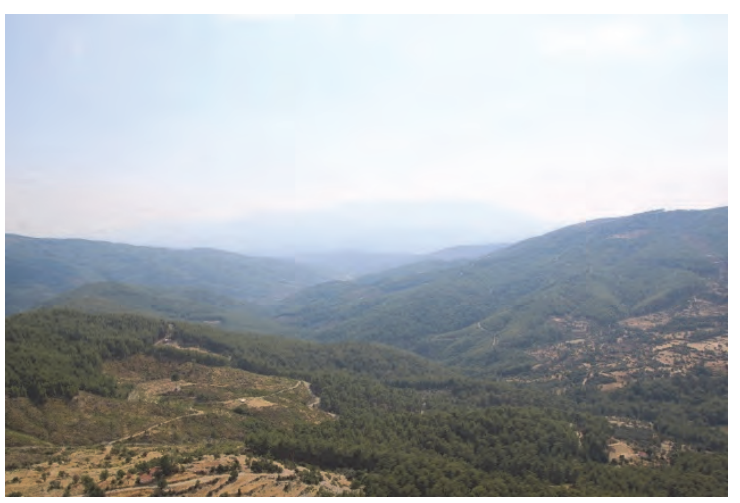

Fig. 9) View from Kayaarasi outpost to the west. Xanthian Valley

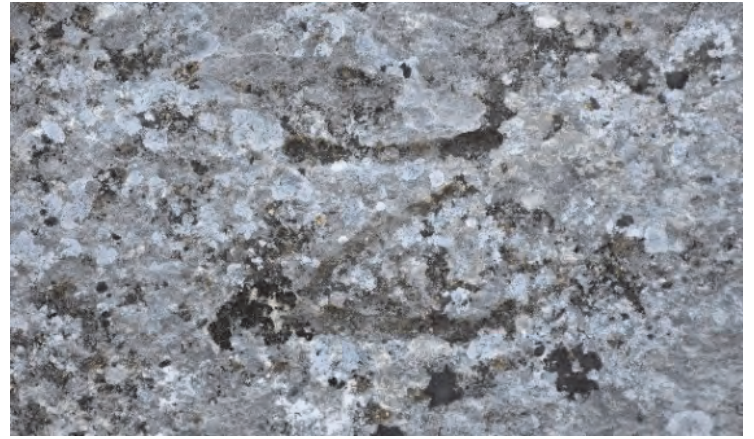

Fig. 6) Köristan. The letter $Z$

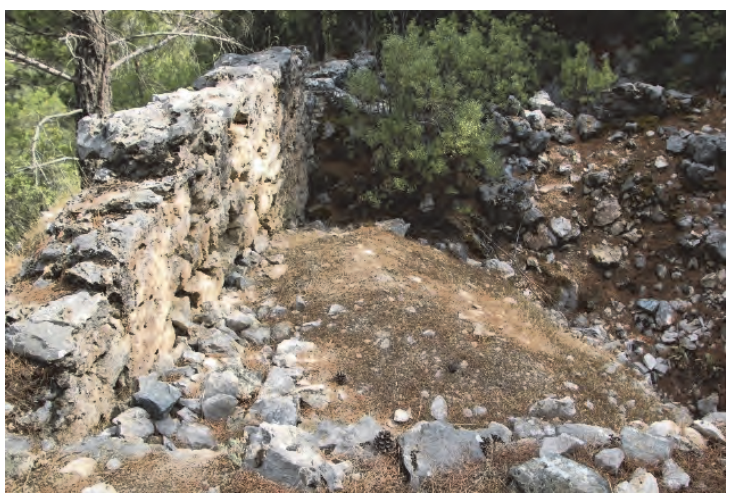

Fig. 8) Kayaarası. The remains of an outpost

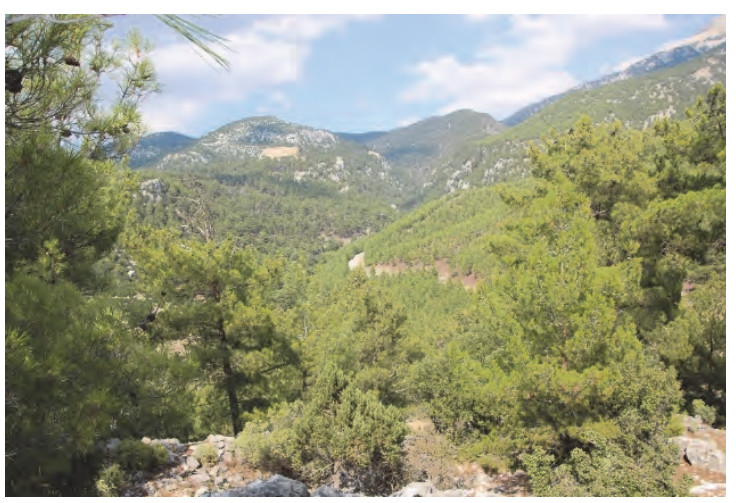

Fig. 10) View from Kayaarast to the east. The course the ancient road 
Figs: The course of the ancient road between Tlos and Oinoanda by Haciosman Stream

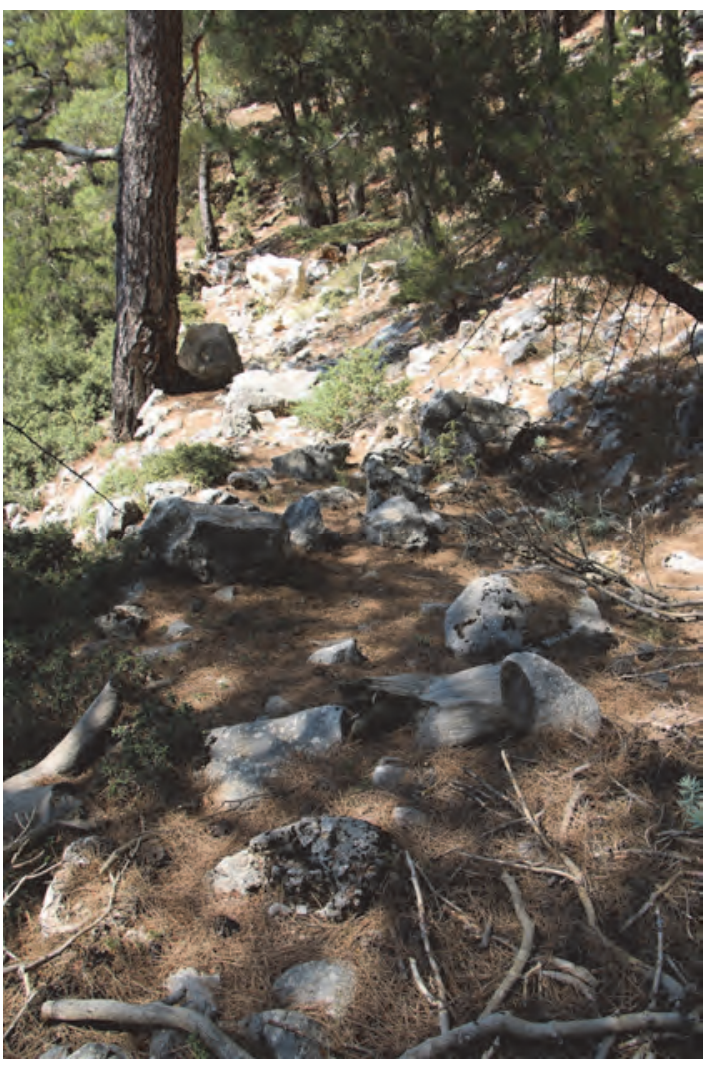

Fig. 11

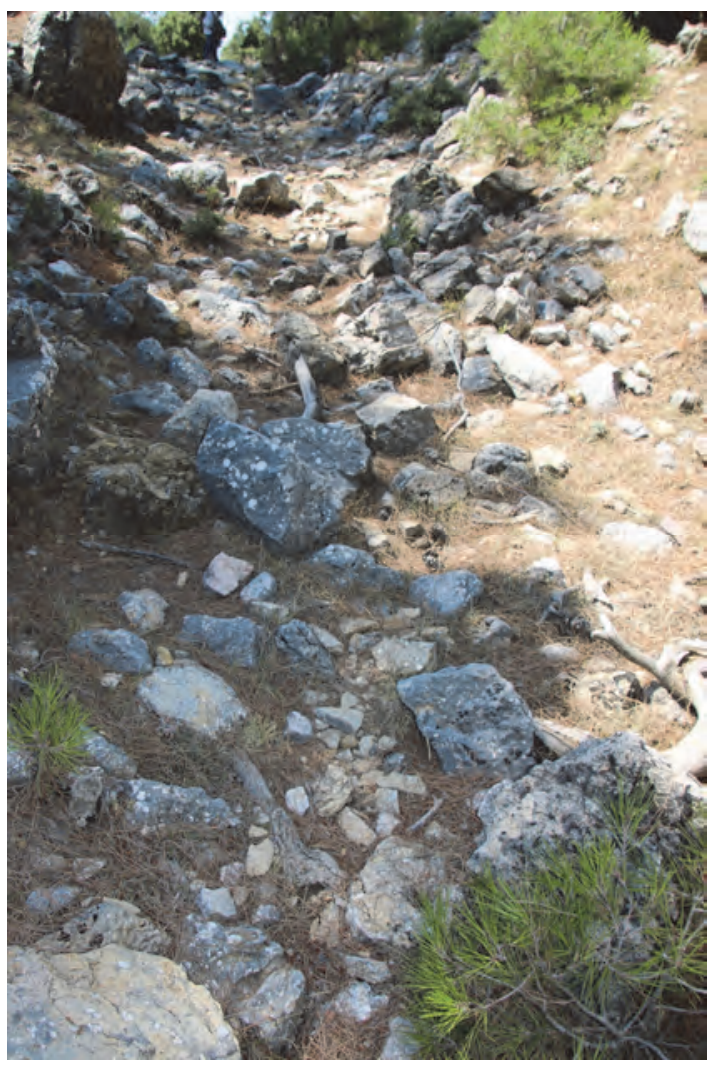

Fig. 12

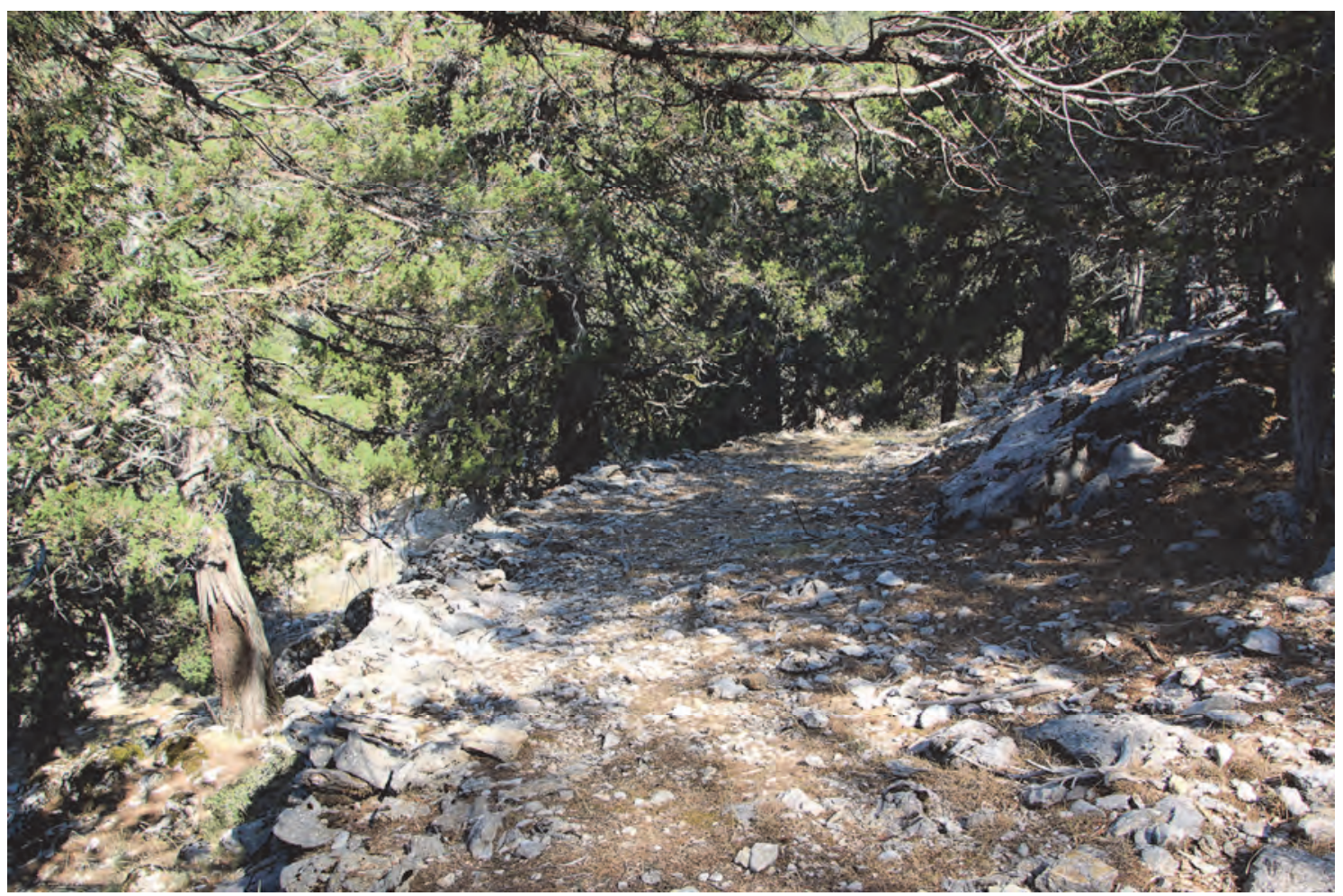

Fig. 13 


\section{The ridgeway from Oinoanda to Tloan Stakes and to the plateaux on the Mount Masa}

There is also another road from Termessos to the "poles/stakes" of Tlos across the mountain (l. 46-49). This road not only connected Termessos/Oinoanda to the Tloan stakes but to the plateaux across the mountain. We learned from our field surveys that this road is still in use, leading from Gökbel Yaylası to the yaylas of Karanız and Makmara, and then perhaps down to the main road through Çökek Yurdu along the eastern bank of Karabağlık ravine. After Makmara, there are also several roads leading to yaylas including Girdev and other places on the mountain. From Gökbel Yaylasi to the north in the direction of Oinoanda, the road leads through Elmaağac1, where there are several rock reliefs and a khamasorion tomb with a quite worn inscription. This road follows the demarcated third ravine (Rv3) leaving it on its western side.

Figs: The ridgeway from Gökbel Yaylası to Karanız Yaylası

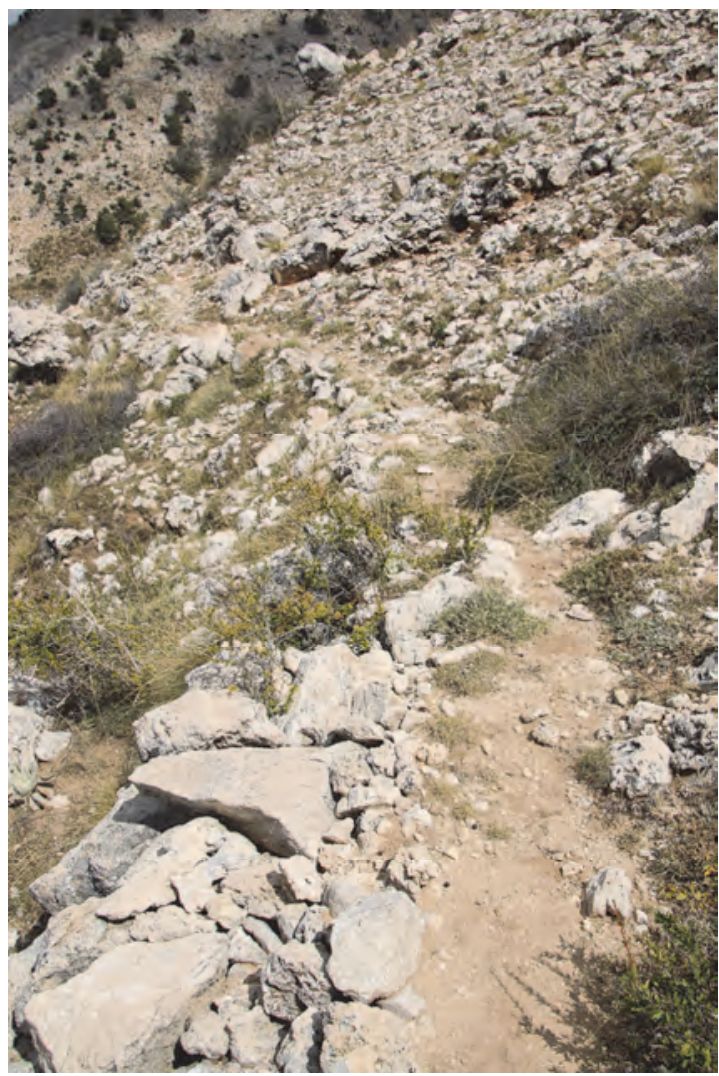

Fig. 14

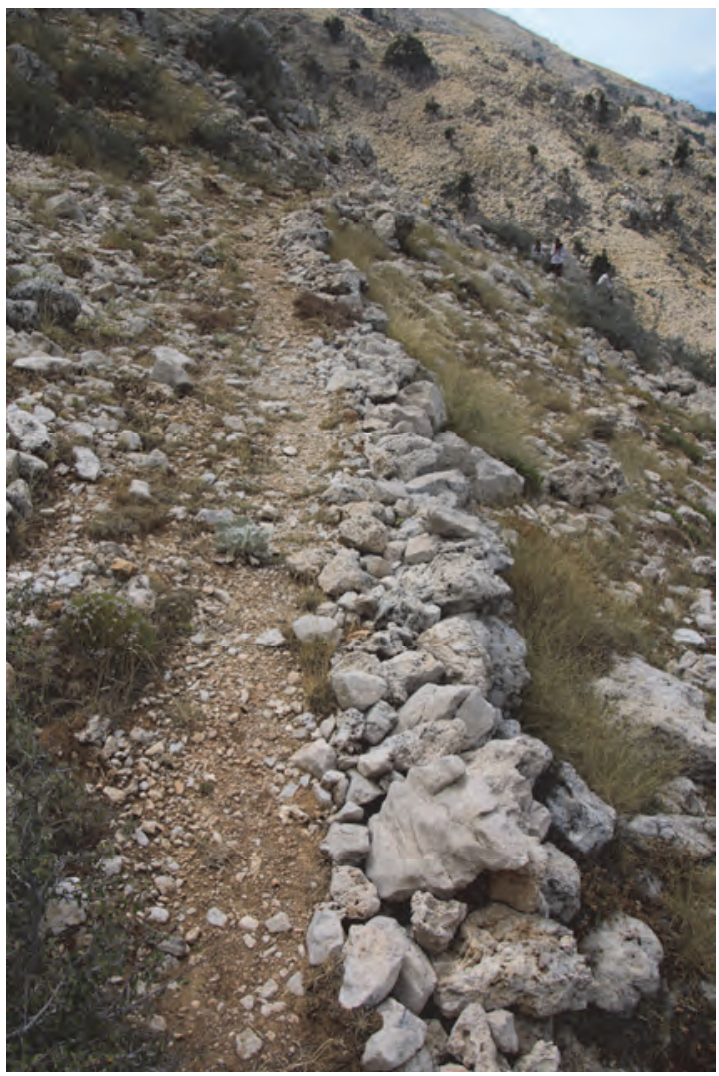

Fig. 15

In 2015 we discovered two marks carved in bedrock on the mountainous section to the east of Makmara Yaylası, one in Makmara and the other in Dumlu, to the south of Oinoanda. The first one (Fig. 19) is carved vertically on a flat high rock, a simple round mark, which cannot be seen from the ground level. A tiny canal connects the hole down to a crack in the rock. So, not only it does not seem to have served as a boundary mark, but it was also outside the demarcated area. The second one (Fig. 20) in Dumlu was carved on an upright rock is a typical boundary mark, with the letter $\Delta$ inside an O. However, this cannot be one of the marks mentioned in the inscription, since it is too far from the demarcated area. The beginnings of 1.66 and 1.70 contain illegible words which are important to understand the destination of the ridgeway for the former (1.66), while a place, where the ascent of Rv3 ends, for the latter (1. 70). 
Figs: The ridgeway from Gökbel Yaylası to Karanız Yaylası

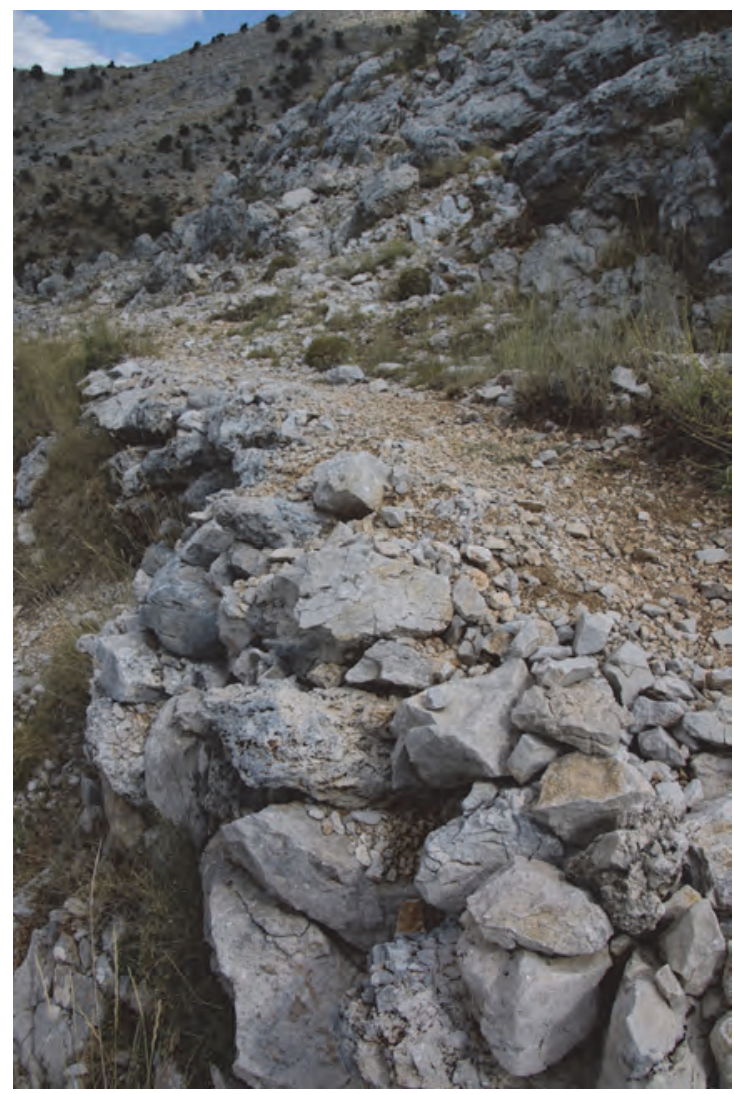

Fig. 16

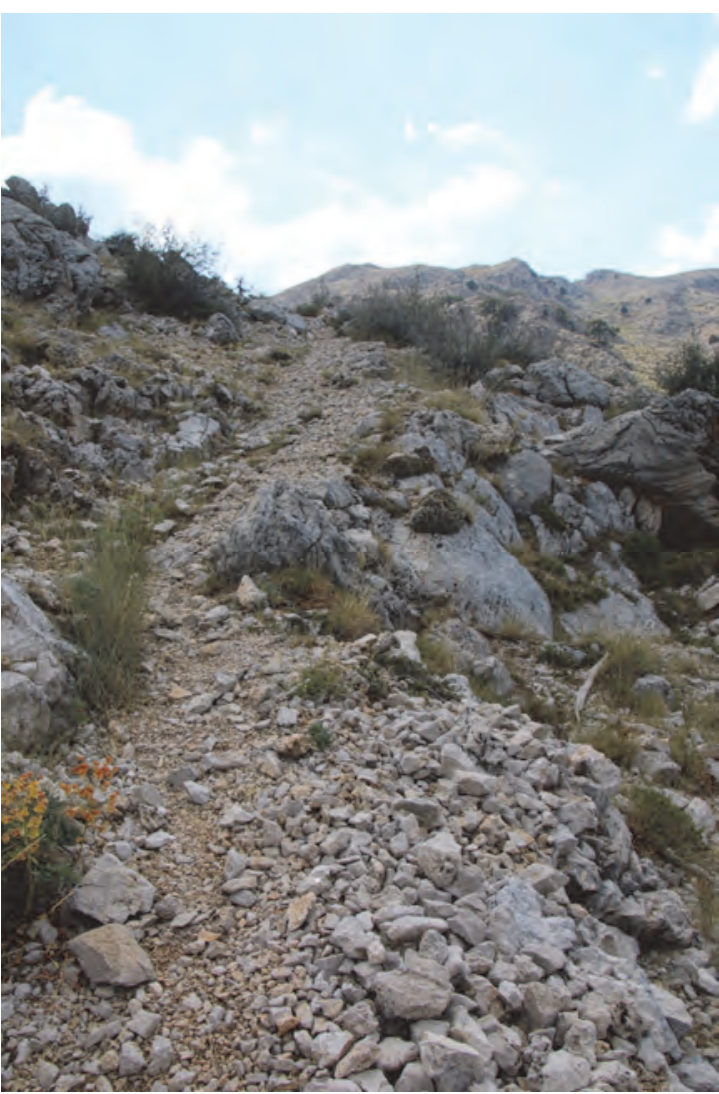

Fig. 17

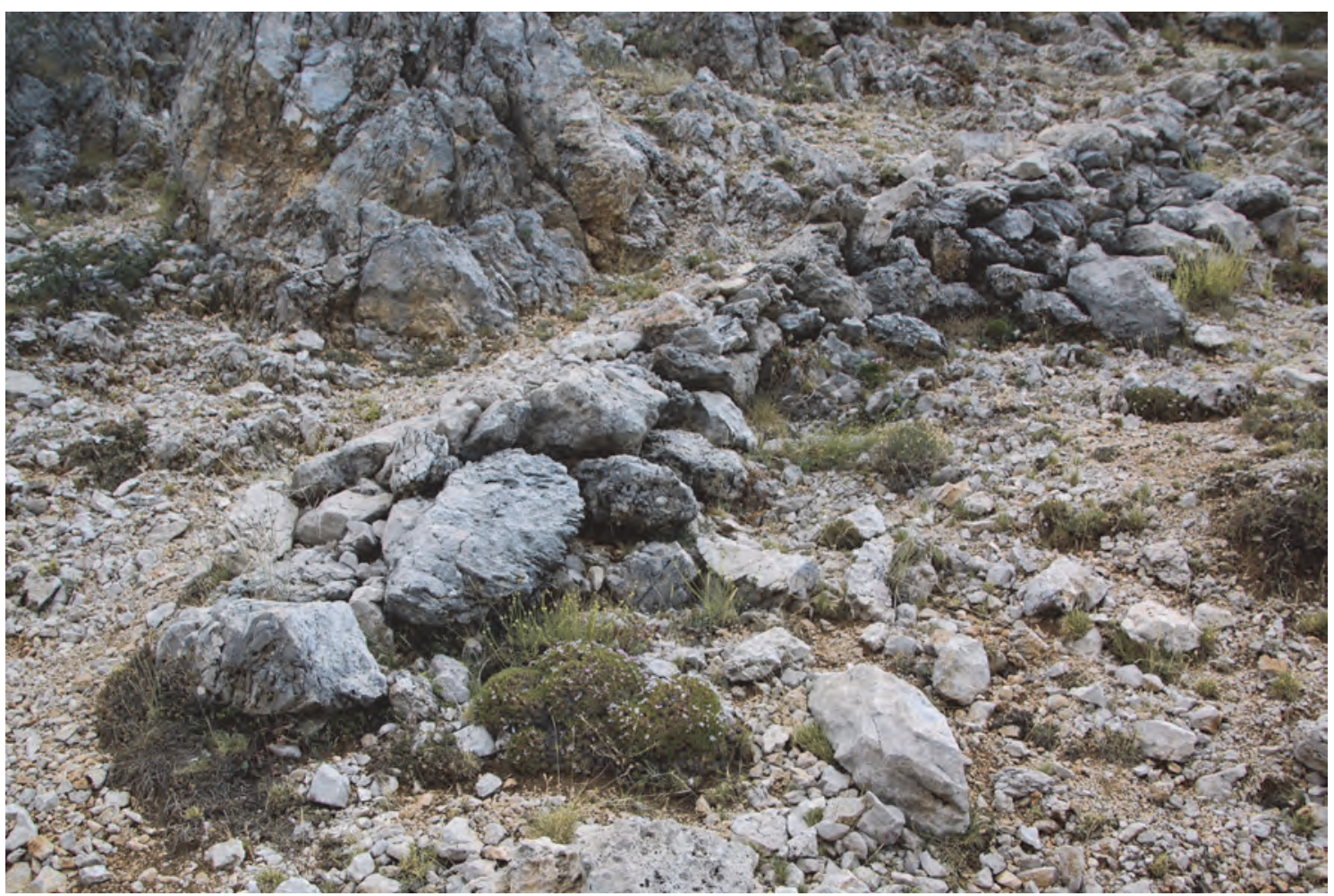

Fig. 18 


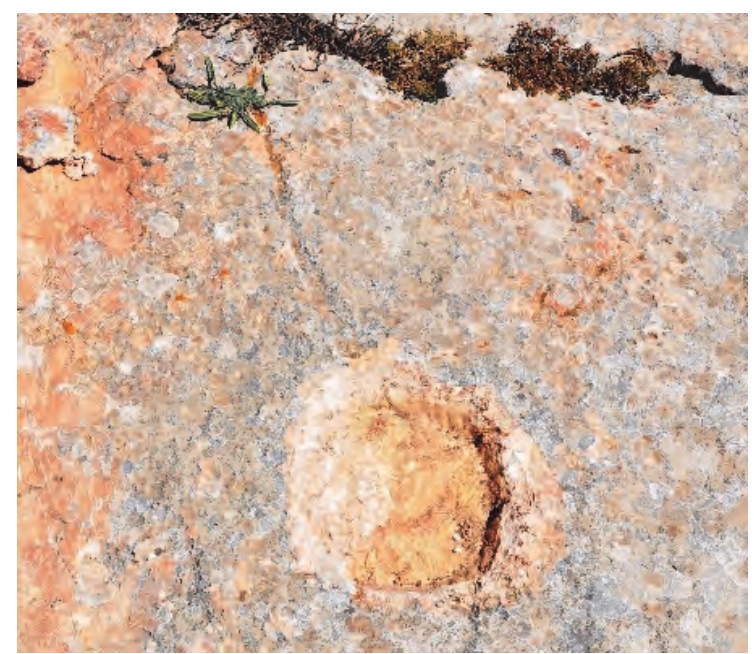

Fig. 19) Makmara. Unidentified horizontal mark, which cannot be seen from ground level, on a high rock.

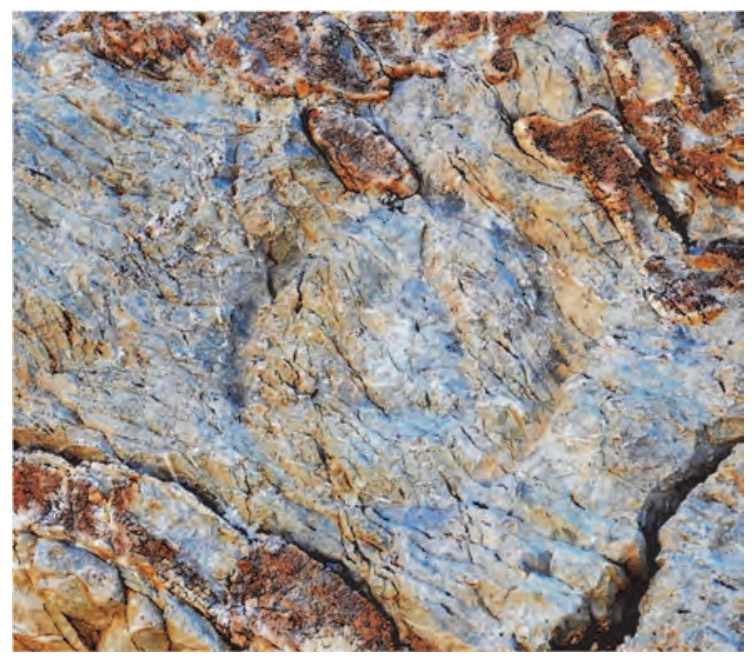

Fig. 20) Dumlu. A boundary mark

The destination of the ridgeway cannot be precisely ascertained, as can also be seen in Rousset's

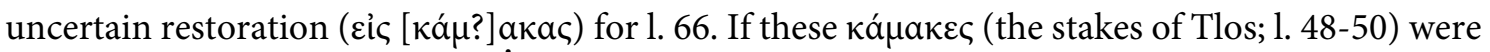
beyond the demarcation area, to the south of the mount, this proposal of restoration is still a possible option. One possibility might be Deliktaş/Darı̈̈zü (Kastabara), since the ridgeway did not make so much sense for those who wished to go to Tlos, because they would have picked the main road along the slopes of Mount Masa. The ridgeway seems to have served as a road to reach the eastern regions such as Girdev and upper parts of Tezli Dere, to the south of which was located the settlement in Deliktaş/Darıözü (Kastabara). This settlement has towers dating from the Hellenistic period, and probably already existed in the time of this inscription. Its location is also

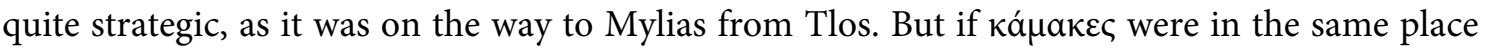
with the pass (diodos; see below pp. 153-155), then we might need to find out if there might be some other options for the possible word. ${ }^{17}$

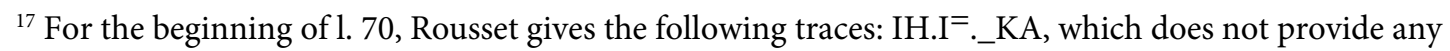
hint of a common geographic description or a place name. One possibility could be that the word ending with -KA might have been the subject of àvateível, which is without a subject in the surviving part of the sentence, but there is no suitable word available in the nominative form. From the construction, it seems that the word ending with -KA here is in the feminine accusative, the article of which is $\tau \eta \dot{v} v$ in the previous

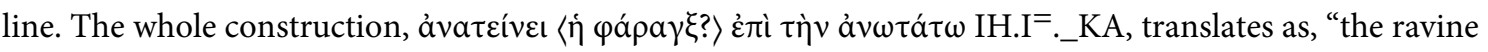

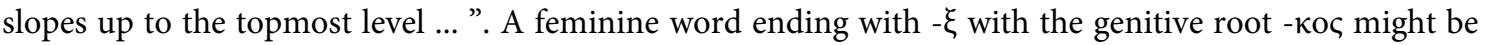

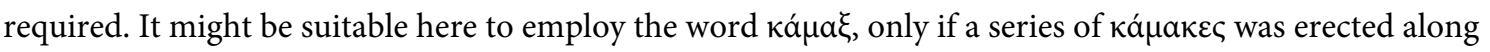
the ridgeway at least up to the plateau, where the ravine ends (see below pp. 155-157). If the word is not a proper name, but the name of a geographical formation or an adjective for a possible preceding word, since its location is described as in the topmost level, the possible words are limited, as it should also not exceed the gap of 7 letters. All that I have been able to find, although this list may be deficient, carry the - $a \xi$ ending: $\lambda \hat{\imath} \theta \alpha \xi$ (stony), $\check{\varepsilon} \mu \alpha \xi$ (heap of stones; cairn), $\kappa \lambda \tilde{\lambda} \mu \alpha \xi$ (step), $\lambda \varepsilon \tilde{\varepsilon} \mu \alpha \xi$ (meadow), $\pi \tilde{i} \delta \alpha \xi$ (spring, fountain), $\beta \tilde{\omega} \lambda \alpha \xi$ (lump, clod of earth), $\dot{\varepsilon} \rho ß \tilde{\omega} \lambda \alpha \xi$ (with large clods), $\pi \lambda \alpha^{\prime} \xi$ (flat land, plain). In the physical geography, the ridgeway reaches the Karanız plateau, while the ravine ends on the western edge of the same plateau. After Karanız, the road continues to the Makmara plateau, from where it also possible to pass to the İğdirce plateau. Further, the boundary mark in Dumlu (Fig. 20) is clearly on the ridgeway to the Girdev plateau. It seems possible that the word in 1.70 might have been $\pi \lambda \dot{\alpha} \xi$, indicating today's Karanız plateau. The same 


\section{The details of the demarcation and their location in the modern geography}

The aim of the topographical description in the text was to define the demarcated area exactly and in detail, thereby preventing any possible confusion to the contracting parties and to contemporaries. The description in the text would have been clear to those who were familiar with the topography. However, matching an ancient description to modern geography is usually difficult, and this is certainly true for a specific area in such a mountainous terrain, even though we have the detailed information, such as ravines, rivers, plateaux (derived from marked flat stones in the text) provided by the inscription. The field survey of 2019 produced firm results concerning the location of Mount Masa and the topographical details in the text. But unfortunately, no demarcation marks were found in the expected area, which is the third ravine (Rv3), except for B2 (see below Fig. 21-Fig. 23), despite several days of searching by the members of the survey team. There are several reasons for this. The nature of the rocks in the area is not durable. The locals call them "Eriyen Kayalar" ("melting rocks"). The surface of the rocks easily splits off. A lot of rock appears to have fallen after earthquakes or as a result of natural erosion, and had fragmented. Geomorphological research is needed to understand the historical progress and conditions. It is also possible that these marks might have already been removed in an earlier period by local people, interpreting them as signs indicating "treasure", though none of those whom we asked knew or had heard about these marks. Another point might be that these boundary marks lost their utility and were not protected after Termessos/Oinoanda was incorporated into Lycian territory. And of course, it is possible that our team might somehow have failed to notice them.

Mount Masa was today's Hacıosman Dağı, the acreage of which is ca. 3300 ha, i. e. ca. 33 square kilometres. ${ }^{18}$ It has three peaks called Hacıosmandağı Tepesi $(2440 \mathrm{~m})$, Karanlık Tepe (2346 m) and Eren Tepe $(2333 \mathrm{~m})$ from north to the south, which constitute the main part of Küçük Akdağlar. On the main road from Tlos to Termessos, only today's Karabağlık Valley on the southern slope of Mount Haciosman north of Tezli River fits the description of the southern ravine (Rv1;1.33-37 and 1. 88-91). The northern ravine (Rv2; 1. 42-49) is today's Deliktaş Valley, the only one that provides an exact cut to separate the mountain from northern range. Therefore, the southern and northern borders of Mount Masa, were defined by these two ravines and the other details mentioned below.

word can also be proposed for 1. 66, taking into consideration these plateaux on the mountain. The word $\pi \varepsilon \delta$ táotoc, ov (an adjective) employed in 1.80 gives a similar meaning. While it could have been a nominal-

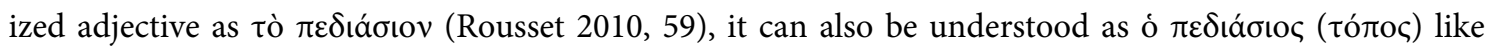

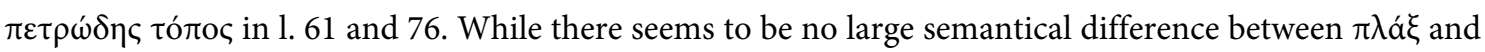

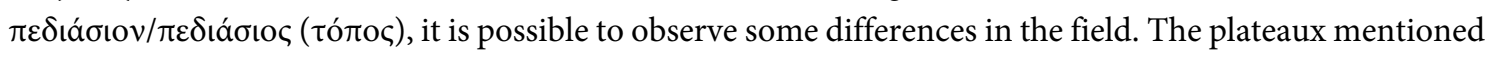
are all large, populated, cultivated and quite suitable for livestock. The area described as $\pi \varepsilon \delta$ iáoı somewhere between the Karanız and Makmara plateaux. This section has some small flat areas, but certainly not for settlement or farming, as they are not large enough, lack sufficient water sources and are surrounded by rocks. Today these small plain areas are only used for grazing. Another possible restoration suggested by

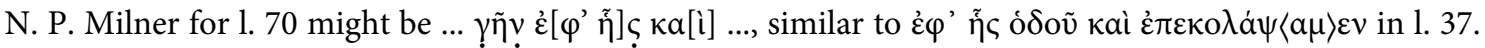
Then the translation of 1. 69-70 would be "as the [ravine] extends up to the land on the highest level, on which we likewise carved a boundary mark on a rock...".

${ }^{18}$ Rousset (2010, 60-61 and 126) estimates this figure ca. 900 ha at most. 
L. 33-38: There are several small ravines which lead down to main road, but only the Karabağllk Valley matches the whole description. This deep ravine is at the south end of Haciosman Dağ1, and separates this section from the whole mountain range. Although the marker B1 could not be found, it meets the road from Tlos to Oinoanda exactly on the road, also the modern road, near Boyall. The distance between the junction points of the southern and the northern ravines with the main road is ca. $9-10 \mathrm{~km}$.

L. 38-44: The demarcation surveyors moved to the northern ravine, which should have separated Mount Masa from the mountain range to the north and which meets the road in a place where

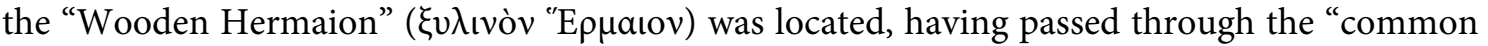
burial-place" ( $\left.\pi \mathrm{o} \lambda \nu \alpha \nu \delta \rho \varepsilon \tilde{I}_{0} v\right)$. Rousset thought that the surveyors were at the top of a ravine (Rv2), right after Hermaion, ${ }^{19}$ but they were actually at the bottom, on the bed/valley of the Golbanounda, since this ravine mentioned in 1. 44-46, Rv2, joins Golbanounda, which after this junction descends within ca. $800 \mathrm{~m}$ to main road. This ravine (Rv2), which descends from the peak of the mountain, is the Deliktaş ravine, which meets the Haciosman stream (ancient Golbanounda) in the lower parts. So, they travelled on the main road, riding in a cart or a horse as the verb

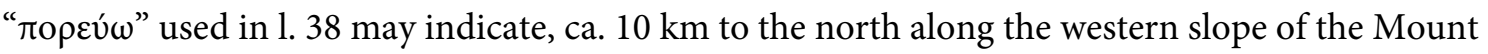
Masa, traversing northwards from one ravine to another, the natural limits to the mountain. The common burial-place between these two points cannot be precisely determined, but Çökek, considering the ancient tombs there, or Kayaaras1, where there is a boundary outpost, are candidates for its location. The "Wooden Hermaion", which was a sanctuary of Hermes as Rousset defines it, ${ }^{20}$ indicates a location on the boundary between Tlos and Termessos where the bed of Golbanounda (Haciosman Deresi) intersected the road. It is not clear on which side of the Golbanounda or the second ravine the Hermaion stood. Most probably it was on the Tloan side, namely to the south of Golbanounda, probably close to the outpost in Kayaarası. Ca. $45 \mathrm{~m}$ from the Hermaion, they reached a point where they were able describe the boundary line. It was a place probably exactly on the boundary, in the lower section of the Golbanounda.

L. 44-49: The commission points a very short distance from the main road on the Golbanounda to the junction of the Golbanounda and the ravine coming from the right. The first ravine which joins the Golbanounda from the right is ca. $800 \mathrm{~m}$ above the road to the northeast, and bringing the Deliktaş Deresi stream. From this confluence, the boundary ran up the Deliktaş ravine to the ridgeway pass located ca. $1 \mathrm{~km}$ east of Gökbel Yaylası. The remains of this second road still exist (see above p. $147 \mathrm{ff}$.). It provides a mountainous route, to northern highlands of Tlos. The distance between the junction of the Golbanounda with the Deliktaş ravine near Hermaion and the pass is $6,5-7 \mathrm{~km}$.

L. 49-56: The boundary followed the Deliktaş ravine, which has several side rocky streams, up to the pass. Today the stream names attached to the ravine are four: the lowest section joins the Haciosman Deresi (Golbanounda), the middle part is called the Deliktaş Deresi; above this is the Kuru Dere, and the upmost section is the Sar1 Dere. As the ancient surveyors reached the pass, they walked ca. $45 \mathrm{~m}$. to the bottom of the ravine (Rv3) entering from the right, which was also the junction with the stream called Endyrenos. At this point they were in the bed of Endyrenos, today's Sarı Dere. The meeting point of the (Deliktaş) ravine to the west, the ridgeway, running

\footnotetext{
${ }^{19}$ Rousset 2010, 57-58 and fig. 43.

${ }^{20}$ Rousset 2010, 57.
} 
on a north-south axis, the third ravine to the south (Rv3) and the River Endyrenos to the southeast, is ca. $1 \mathrm{~km}$ southeast of Gökbel Yaylası. This point is the most precise location in the text. Exactly as described, there is a rock at this very point (1. 54), on which there seems to be a worn "O" (öpoc / "boundary") sign, $45 \mathrm{~cm}$ in diameter (B2; Fig. 21-Fig. 23).

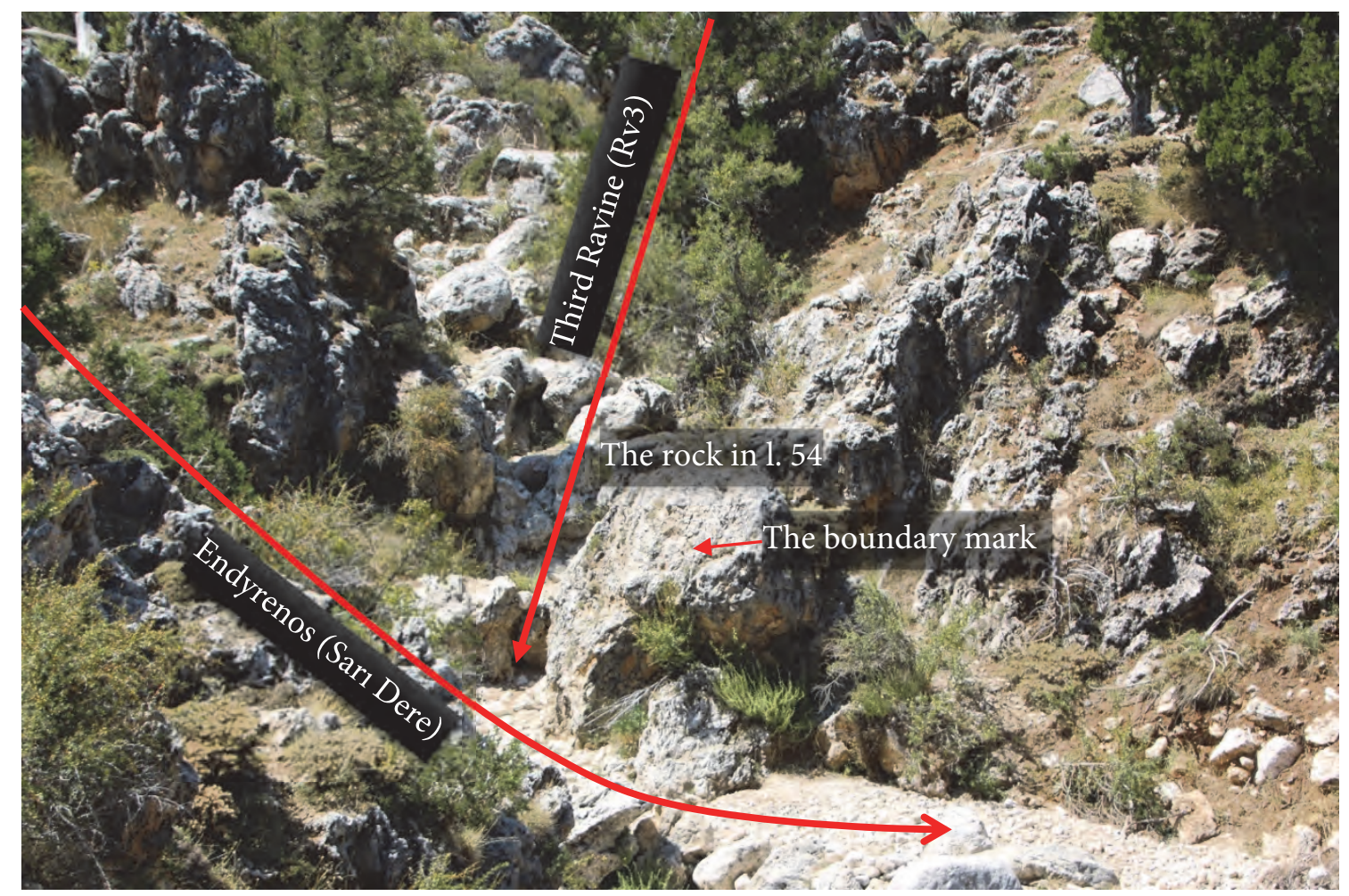

Fig. 21) Gökbel Yaylası. B2 is visible as a large "O" on the rock (in middle) in the junction of Endyrenos (Sarl Dere) and the ravine on the right (Rv3)

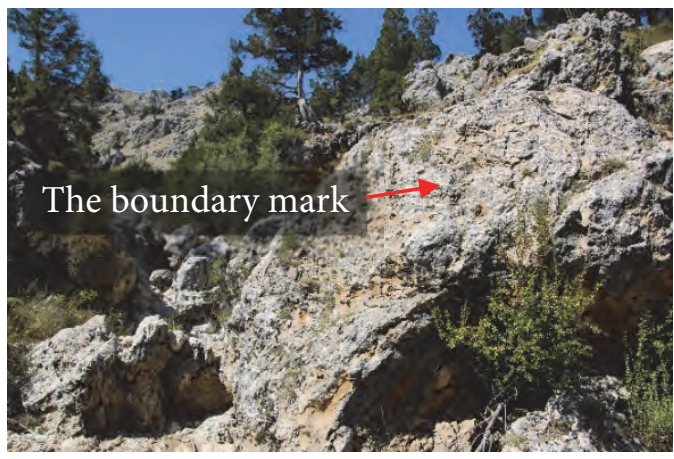

Fig. 22) B2 on the rock

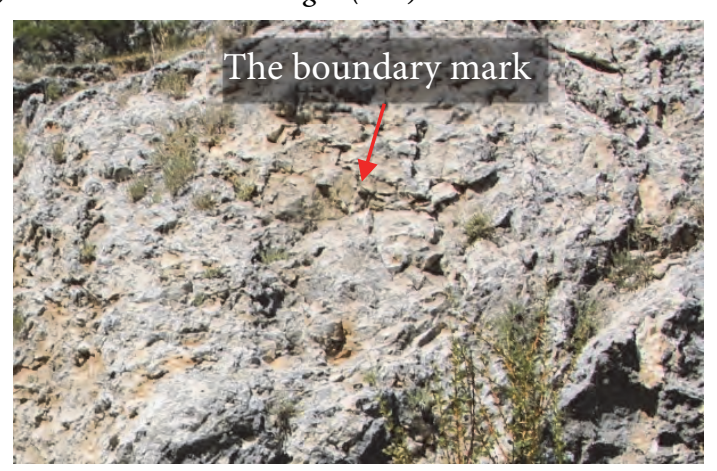

Fig. 23) B2 on the rock

The surveyors did not need to mark the ca. $18 \mathrm{~km}$ section between B1 and B2, which is near to the pass up on the mountain, since the Hermaion on the road and the ravine running from the river Golbanounda to the pass and to the Endyrenos, clearly defined the northern and north-western

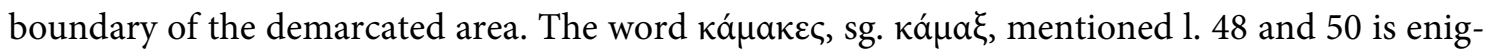
matic. Its primary meaning is "vine-pole, vine-prop" ${ }^{21}$ Rousset's first suggestion is that this was a fence made of wooden poles to delimit a certain area, but he also gave a lengthy account of the word's primary meaning, which Şahin also accepted. Both associated the term with viticulture in

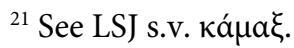


the area. ${ }^{22}$ However, the geographical and topographical features of Haciosman Dağ able for viticulture. The altitude in the northern mountainous part of the demarcation, namely from diodos near the Gökbel Yaylası to the top of the first ravine near Çökek Yaylası, ranges between ca. $1750 \mathrm{~m}$ and ca. $1870 \mathrm{~m}$. Grapes at this altitude have a very short ripening period and can only be cultivated with great care. Weather conditions including heavy showers, hail, and strong winds can pose great problems for vine cultivation, and yields would be too low for the high effort involved, although the product might be of high quality. ${ }^{23} \mathrm{~A}$ research group investigating the potential for grapevine cultivation in Turkey shows that the area of Akdağlar does not meet the conditions for production, and in their map the area is indicated as "uygun olmayan" ("unsuitable"). ${ }^{24}$ Vineyards might, however, have existed nearby in Gökbel Yaylası or on the northern banks of Tezli Dere, where there are south-facing sunny slopes at an altitude of ca. $1300 \mathrm{~m}$. Another suggestion for the meaning of кá $\mu \alpha \kappa \varepsilon \varsigma$ is that they formed a ford or causeway, marked by stakes. Poles marking the ford on the Saklıkent River can be seen in the painting of "Turkish Merchants crossing the River Mangerchi" by William Müller of 1845, showing that this ancient tradition persisted until recent times. ${ }^{25}$ The "Tloan Stakes" might refer to a ford on River Endyrenos, which would have formed the boundary itself, or they could have been stakes designed to stick out above the snow in winter, to mark a pathway, as there was enough winter snow, as is today, on the region for this to have been necessary.

Rousset prefers to locate "Tloan stakes" out of the demarcated area, while Şahin thinks that it was in the same place with the pass (diodos in 1. 47-49; see also p. 147 above) of the ridgeway (see here fn. 22). This difference originated from their different approaches to the word हlo $\sigma \varepsilon$ in 1. 48: Rousset accepts a meaning identical to $\mu \varepsilon ́$ x $\rho$, while Şahin takes it as "namely" ("yani" in Turkish), ${ }^{26}$ so the former accepts it as a destination of the ridgeway to the south, the latter as the upper end of the ravine in diodos. As Rousset points out (see. fn. 26), the meaning of the word $\varepsilon$ i' $\sigma \tau \varepsilon$ is uncertain.

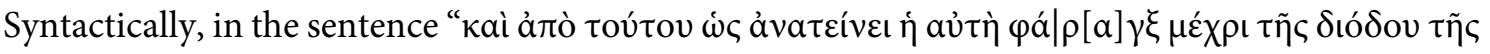

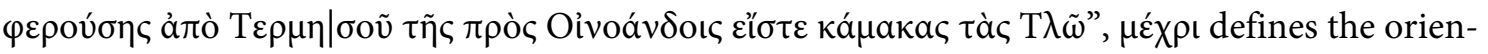

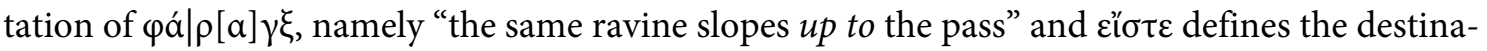
tion of "the ridgeway, which leads to the stakes of Tlos (as well)". So, the meaning of "namely"

${ }^{22}$ Rousset 2010, 22 and 120, see also fig. 43 (here Fig. 1 above). However, he cautiously kept the word in translation as "pieux", i.e. "stakes” or "poles"; Şahin 2014, 217, see also his sketch in ibid, 219 (here Fig. 2 above). He translates it as "Tlos Bağları" in Turkish, i. e. "vineyards of Tlos".

${ }^{23}$ Korkutal - Bahar - Özge 2012, 26-28.

${ }^{24}$ Alsancak Sirlı et al. 2015, 57, 60 and fig. 2.

${ }^{25}$ Wallis - Chamberlain 1896, 7 no. 30 (a photo of the painting is between p. 10 and 11). Solly 1875, 294295 described this painting as following: "The dark river swollen by recent rains is rushing impetuously over a rapid and the water is tumbling amidst rocks and the broken stumps of trees in the immediate foreground. The ford is indicated by tall poles placed here and there in the bed of the river, where some four or five baggage camels, led and urged on by their turbaned drivers, are seen fording the stream. On the left, some Turks are seen, kneeling near piles of picturesque oriental baggage strewn around; a kneeling camel shows they are occupied before crossing in readjusting the loads on the patient beast. Several other Turks, and one or two camels are standing near. On the far side of the river (the extreme right), underneath a rocky bank, the caravan appears to have just encamped, a number of Turks being collected around watch-fires."; see also Duggan 2017, 506-508.

${ }^{26}$ Rousset 2010, 55, 58; Şahin 2014, 217. 
may logically make sense, since diodos and the stakes might have been in the same place. So, to

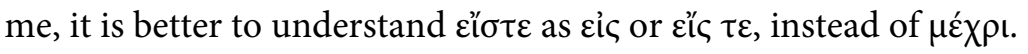

L. 56-65: The surveyors turned right in the direction of the кá $\mu \alpha \kappa \varepsilon \varsigma$, and entered the ravine (Rv3) between Yaylacık Tepe and Çataloluk Sırtı, leading south to the Karanız plateau. Remains of an ancient route leading up to Karanız, Makmara and other plateaux are still visible on the eastern side of this ravine (s. p. 147-15 above and Fig. 14-Fig. 18). There is also a pathway on the western side of the ravine, but it could only be followed until a rocky area.

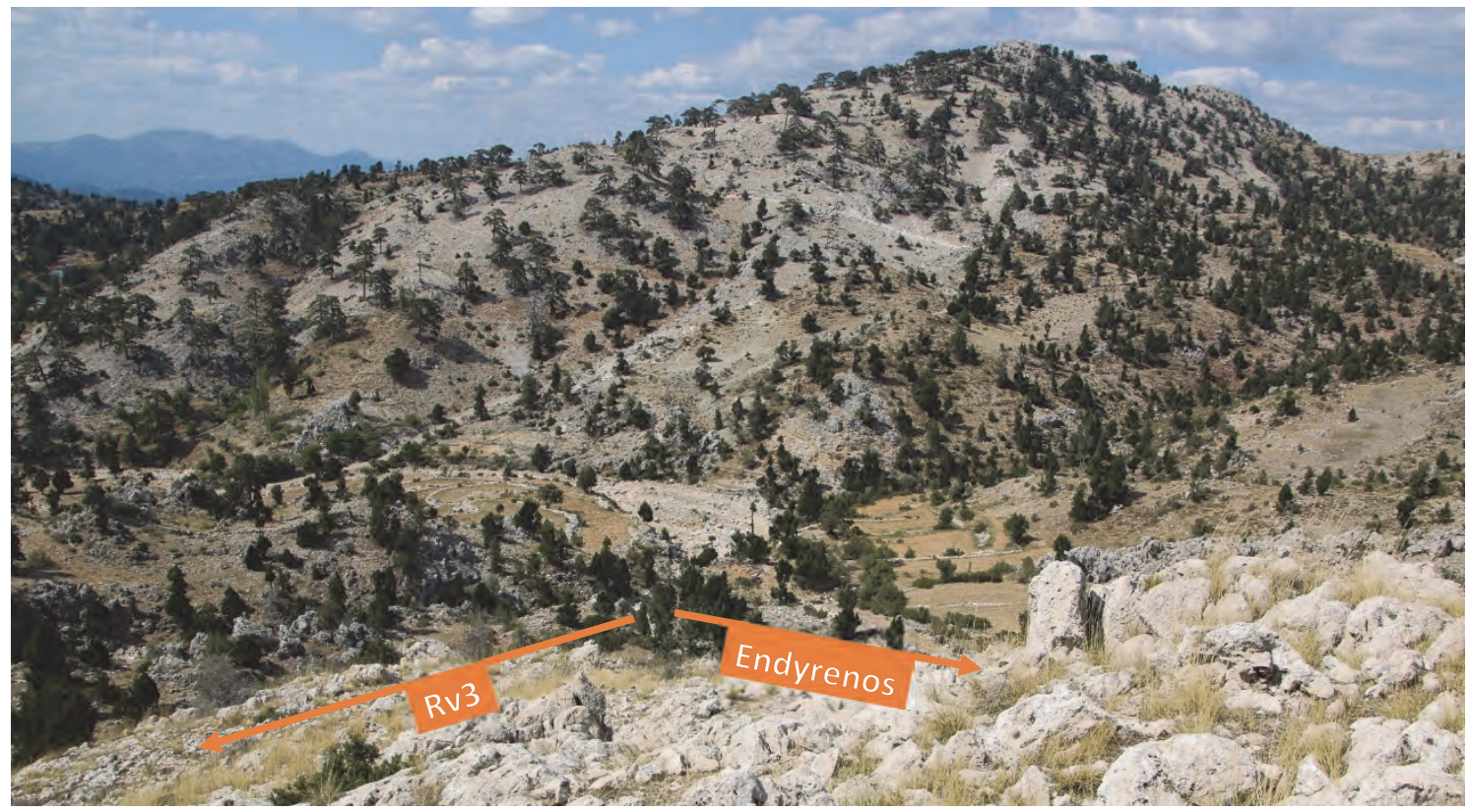

Fig. 24) View to the north from the ridgeway. "Diodos" in the middle, as the junction of the Endyrenos (to the right, Sart Dere) and Rv3 (to the left), which joins it "from right". East of Gökbel Yaylasi.

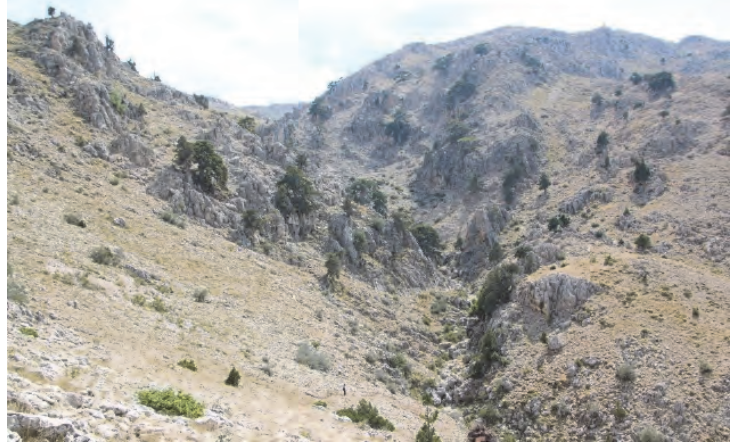

Fig. 25) View to the south. Rv3 sloping up to Karaniz Yaylasi

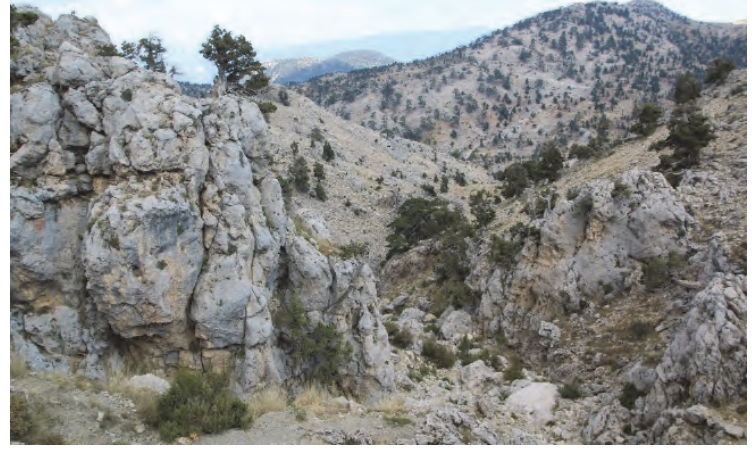

Fig. 26) View to the north. Rv3 sloping down to diodos near Gökbel Yaylası

L. 65-70: Here it is understood that the ridgeway was close on the left-hand side. After B7 the surveyors crossed the road and continued with the road on their right. Here we also see that the ascent of the ravine ended with B11. Then they started to walk on the level plain.

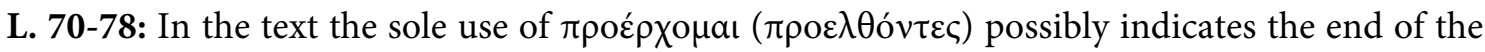
ascent and the entrance into the plain, since they finally reached the plateau, today called Karaniz Yaylası. Here they started to use flat rocks, as in this level area there are not many high rocks on the way. 


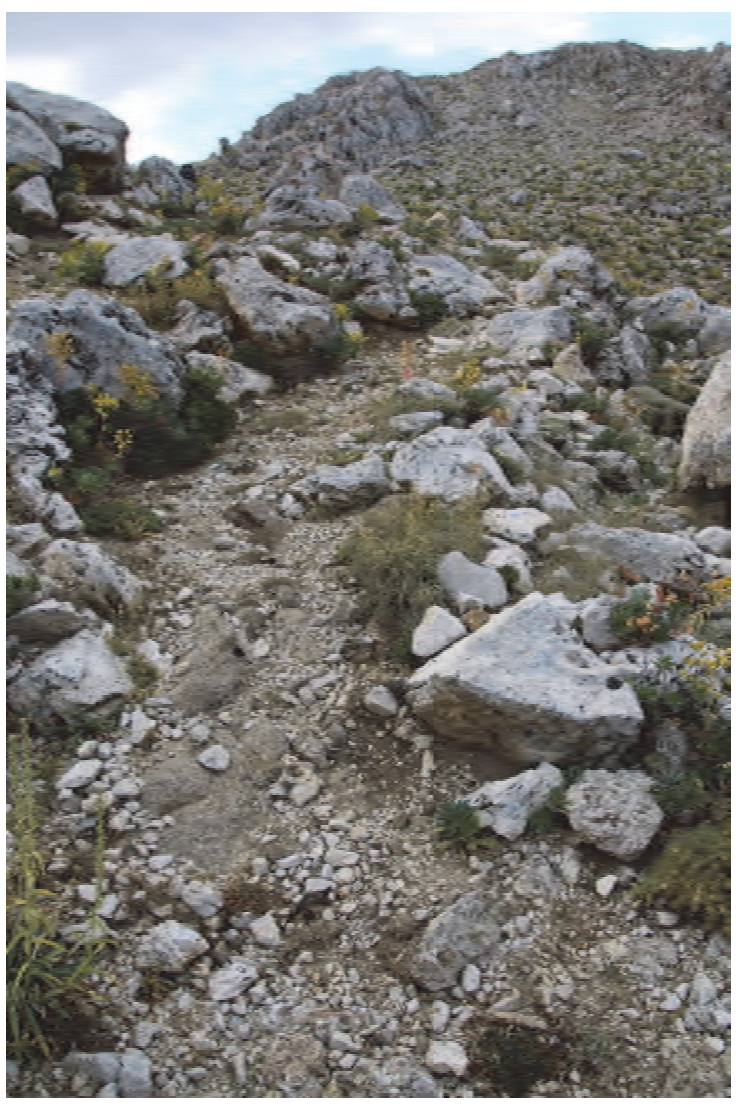

Fig. 27) The last parts of the old ridgeway leading to the Karaniz Yaylası

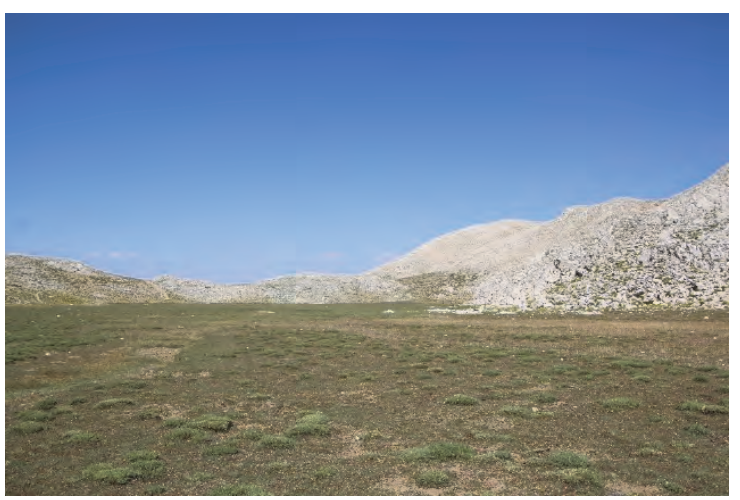

Fig. 30) Northern end of Karanız Yaylası

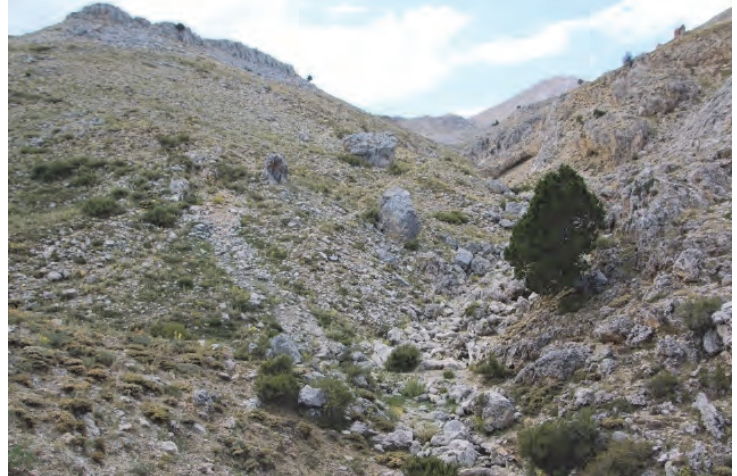

Fig. 28) View to the south. Rv3

sloping up to the Karaniz Yaylast

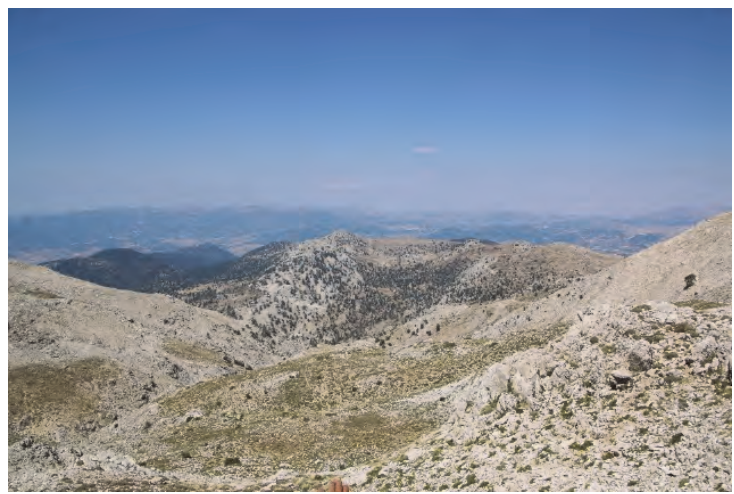

Fig. 29) View to the south. At the top of the Rv3, near to the northern edge of the Karaniz Yaylasi

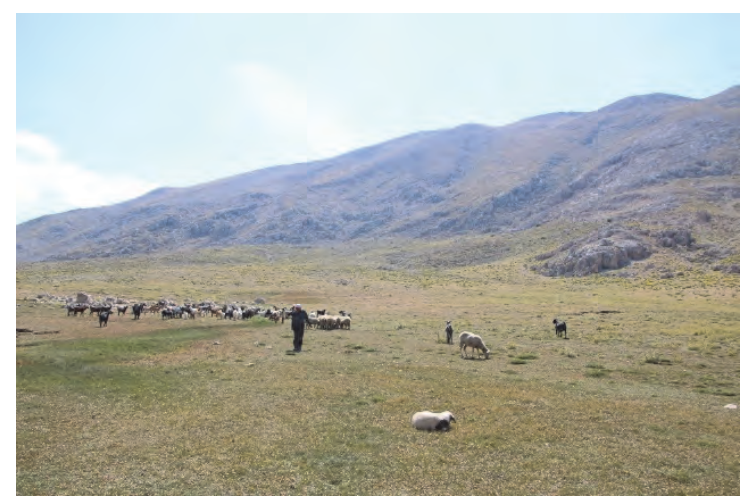

Fig. 31) Karanız Yaylası, view to southwest

L. 78-87: In this section a small plain, a $\pi \varepsilon \delta$ เó $\sigma ı v$, is mentioned, near which B15 was carved on a vertical rock. This should be one of the rocks in the small plains we walked through close to the defile. After B16, the surveyors turned right and crossed the defile (aủxๆ́v), leading to Sarıçukur and Teke Pınarı, as this is the only pass to the summit between the peaks of Haciosmandağ Tepesi $(2440 \mathrm{~m})$ and Karanllk Tepe $(2346 \mathrm{~m})$. The surveyors crossed the mouth of the defile that ran to the east and continued south. They carved the last two boundary marks on the flat rocks on this side of the defile. In the text, the total distance given between B10 and B18 is ca. 1,142m, a length, which fits the distance between the western edge of the Karanız Plateau and a point a little beyond the defile. B13 is carved on a "stony place", while B14 was carved after ca. $31 \mathrm{~m}$ and B15 after ca. $185 \mathrm{~m}$ in vertical positions in the middle of the plain. There is actually a semi-vertical rocky section to the western end of the plain, which fits with the distance, but no sign could be found on these 


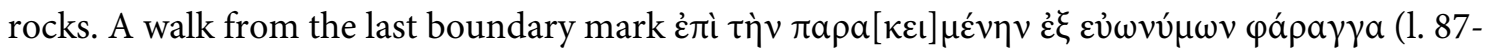
88 ), ca. $3 \mathrm{~km}$ to the south, took them to the top of the first ravine (Rv1), through which the boundary passed down to $\mathrm{B} 1$ at the bottom of the Karabağl1k Valley.

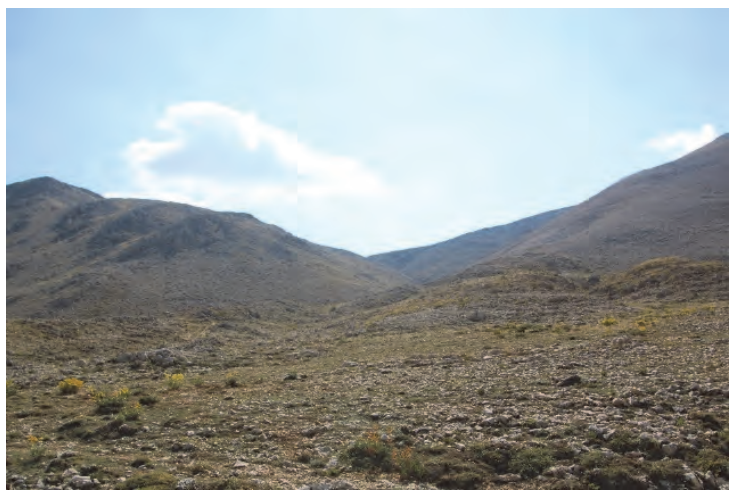

Fig. 32) The defile. View to the west

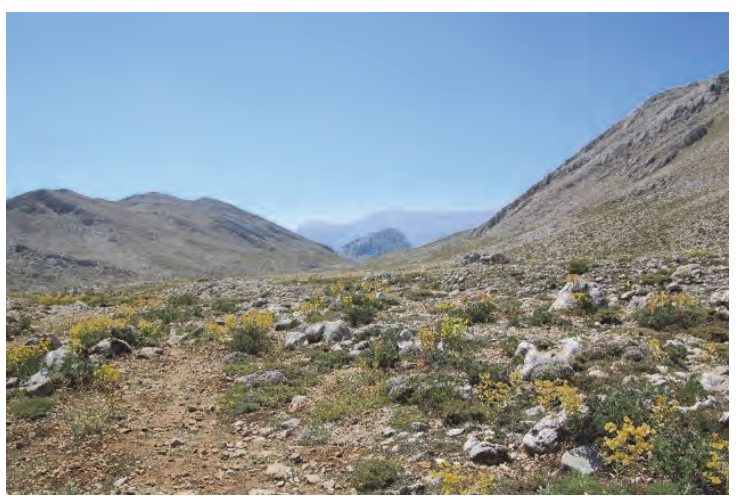

Fig. 34) View from the eastern end of the defile to south, to the top of the Rv1

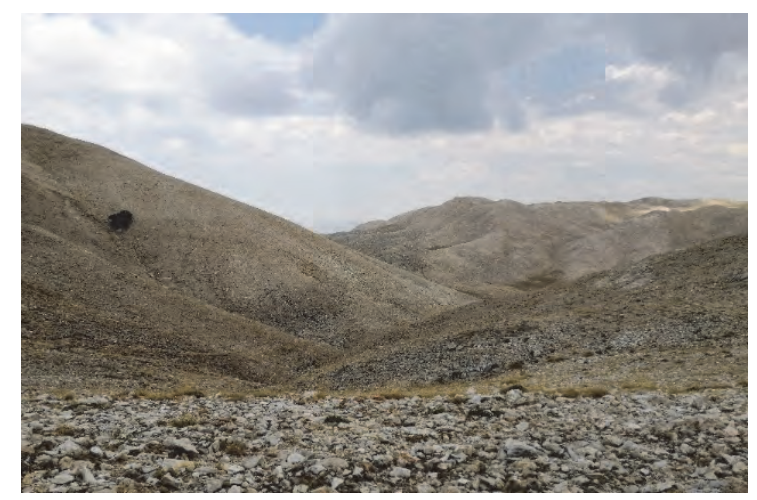

Fig. 33) The defile. View to the east

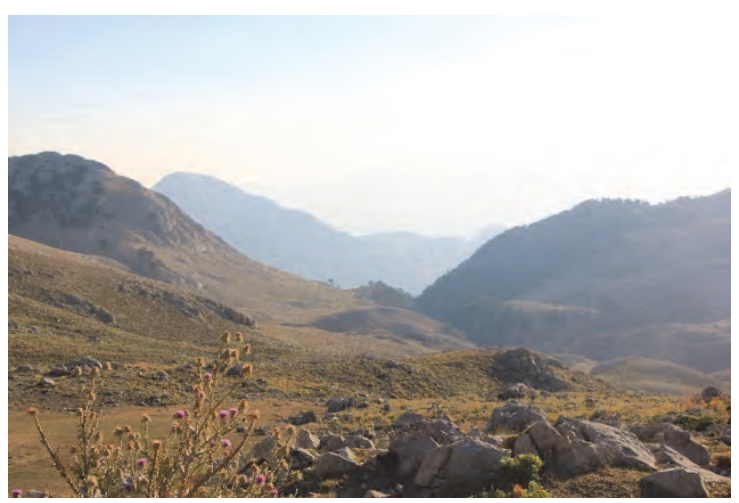

Fig. 35) The top of the Karabağglk Ravine (Rv1)

\section{Closing remarks}

This geographical investigation made throughout the area between Tlos and Termessos showed that there is no mount, which fits with all descriptions - nor in fact another with even a 50 per cent fit - other than Hacıosman Dağı. The identification of Mount Masa as today's Haciosman Dağ 1 raises questions regarding the territories and frontier between Tlos and Termessos, both in the Hellenistic Period and in the Roman Imperial Era. The result of these geographical investigations has shown that Tloan, and so north Lycian territory extended to the northern end of Hac1-

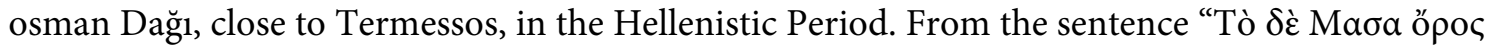
$\varepsilon \tilde{\sigma} \sigma \tau \omega \mathrm{T} \lambda \omega \varepsilon \dot{\omega} \omega v^{\prime}$ in 1.27 of the text, it is understood that Mount Masa was not within territory of Tlos earlier or it was a matter of debate, which was solved through this convention. However, the Termessans' claim on the mount indicate its proximity to Termessos and that the Termessans earlier benefited from the mount. One of the questions with this localization seems to be the territorial affiliation of Çökek, which is located on the southwest slope of Hacıosman Dağı. We have no direct evidence as to the ancient affiliation of this site. Rousset citing Robert's claim and based upon two inscriptions, BCH 24 (1900) 341, 2 (Seki) and TAM II 713 (Çökek), which carry iden-

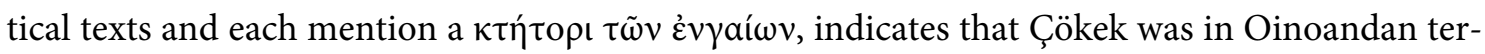
ritory during the Imperial Era, since these identical inscriptions most probably honoured the 
same person, who was the "possessor" of the lands in the same territory, namely in that of Oinoanda. ${ }^{27}$ If Çökek was within the territory of Oinoanda in the Imperial Period, the question arises as to how Tloan territory, which included Hacıosman Dağı in the Hellenistic period, became reduced to the south of Çökek, i.e. Tezli Dere.

We know from the MP that these two cities were no longer neighbours, since a settlement called Plata[...] flourished between Tlos and Oinoanda (see above fn. 13), Kastabara was probably also another settlement between these two and Khoma, and so the territory of at least one, and probably both cities, as the MP shows, would have been reduced to make room for Plata[...] and also Kastabara, which was in the territory of Tlos in a later period in the imperial era. ${ }^{28}$ Perhaps, when Termessos was integrated into Lycian territory, it might have made possible only with the condition that the Termessans should be given Mount Masa, as the northern border of Lycia had often caused conflict with the northern neighbours. ${ }^{29}$ As we know from the foedus (see above fn. 2), Caesar re-assured the preservation of the Mount Masa in Lycian territory, or handed it over to Lycians. In this treaty, we see many place names, which were indicated as within the Lycian territory, while some of these later re-appear as the villages of Oinoanda in the imperial period, such as Marakanda, Ouauta and Elbessos. ${ }^{30}$ It can also be seen that the settlements on the northern border drawn in the foedus follow a near-straight line from the west to the east, and the location of Hacıosman Dağ falls within this line, aligned at least with most of the names mentioned. We do not know what exactly happened in this duration. Even though these all are simply assumptions, it is clear that there was a new territorial arrangement, affecting the boundary between the lands of Termessos/Oinoanda and Tlos, dating back at least to the time when Lycia became a province of the Roman Empire, or to the time when Termessos became integrated into Lycia. In any circumstance, one should pay attention to that this was essentially a circular demarcation of Mount Masa, not of the boundary line between Tlos and Termessos, which most probably coincided only with some sections of the demarcation. ${ }^{31}$ Further investigation of Mount Masa is needed, not only to understand the territorial issues, but also to determine what made it so special in terms of its strategic, economic and common use for grazing and wood cutting. For this we are planning a more comprehensive and interdisciplinary research using modern geographical devices and methods.

\section{Bibliography}

Akyürek Şahin et al. 2017a N. E. Akyürek Şahin - F. Onur - M. Alkan - M. E. Yıldız, Surveys on the Transportation Systems in Lycia/Pamphylia 2016 - Likya/ Pamfilya Ulaşım Sistemleri Yüzey Araştırması 2016, ANMED 15, 2017, 203-212.

${ }^{27}$ Rousset 2010, 116-118.

${ }^{28}$ For the status of Plata[...] and Kastabara, and the earlier results of field surveys in the area see above fn. 12, see also Onur 2016, 92 and Onur 2017, 289-292, cf. Rousset 2010, 142-144.

${ }^{29}$ Mitchell 2005, 227-230; See also Rousset 2010, 127-141 for the relevant comments on the Othagoras inscription from Araxa (SEG 18, 570), Hellenistic Treaty from Boubon (SEG 57, 1637) and foedus (above fn. 2).

${ }^{30}$ SEG 38, 1462, 1. 74-76 (Oinoanda. Documents concerning the foundation of C. Iulius Demosthenes, 124-125/126 A.D.); cf. Rousset 2010, 141.

${ }^{31}$ Rousset 2010, 51-52. 
Akyürek Şahin et al. 2017b N. E. Akyürek Şahin - F. Onur - M. Alkan - M. E. Yıldız, Likya/Pamfilya Ulaşım Sistemlerinin Epigrafik ve Tarihi Coğrafik Açılardan Araştırılması 2015 ve 2016 Yılları Sonuçları, AST 35/1, 2017, 387-410.

Alsancak Sırlı et. al. 2015 B. Alsancak Sırlı - M. Peşkircioğlu - H. Torunlar - K. A. Özaydın A. Mermer - S. Kader - M. Tuğaç - O. Aydoğmuş - Y. Emekliler Y. Yıldırım - S. Kodal, Türkiye'de Üzüm (Vitis spp.) Yetiştirmeye Uygun Potansiyel Alanların Coğrafi Bilgi Sistemleri (CBS) Teknikleri Kullanılarak İklim ve Topoğrafya Faktörlerine Göre Belirlenmesi, Tarla Bitkileri Merkez Araştırma Enstitüsü Dergisi, 24/1, 2015, 56-64.

Courtils - Laroche 2003 J. des Courtils - D. Laroche, Xanthos et le Létôon. Rapport sur la campagne de 2002, Anatolia Antiqua 11, 2003, 423-456.

Çevik 2015

Duggan 2017

N. Çevik, Lykia Kitabı, İstanbul 2015.

T. M. Duggan, $19^{\text {th }}$ Century Ottoman Lycia, British Travellers' Record of The Cingans-Zincani, The Yurook-Yourooks and Turcomen Nomads: on Leeches Erroneous Titles and Dates, Cedrus, 5, 2017, 463-530.

Güner - Ertürk 2005 İ. Güner - M. Ertürk, Fethiye'de Yaylalar ve Yaylacıllk, Doğu Coğrafya Dergisi, 10/14, 2005, 141-178.

Korkut 2014

T. Korkut, Tlos Antik Kenti ve Çevresi Yüzey Araştırmaları, AST 32/1, 2014, 505-524.

Korkut 2015a

T. Korkut, Tlos, İstanbul 2015.

Korkut 2015b

T. Korkut, Arkeoloji: Arkeolojik Kalıntılar, in: T. Korkut (Ed.), Arkeoloji, Epigrafi, Jeoloji, Doğal ve Kültürel Peyzaj Yapısıyla Tlos Antik Kenti ve Teritoryumu, Ankara 2015, 12-147.

Korkutal - Bahar - Özge İ. Korkutal - E. Bahar - K. Özge, Rakımın Üzüm Kalitesi Üzerine 2012 Etkileri, Trakya Univ J Eng Sci 13/1, 2012, 17-29.

Le Roy 1996

M. C. Le Roy, Une convention entre cités en Lycie du Nord, CRAI 140/3, 1996, 961-980.

Mitchell 2005

S. Mitchell, The Treaty between Rome and Lycia of 46 BC (MS 2070), şurada: R. Pintaudi (Ed.), Papyri Graecae Schøyen (Papyrologica Florentina 35), Firenze 2005, 164-259.

Onur 2016

F. Onur, Parerga to the Stadiasmus Patarensis (16): The Roads, Settlements and Territories, Gephyra 13, 2016, 89-118.

Onur 2017

F. Onur, Patara Yol Anıtı Çerçevesinde Kentler, Kırsal ve Yol Ağı, şurada: Ü. Aydınoğlu - A. Mörel (Edd.), Rural Settlements and Urban Centers in Mediterranean during Antiquity/Antik Dönemde Kirsal ve Kent, Mersin 2017, 282-301.

Rousset 2010

D. Rousset, De Lycie en Cabalide: la convention entre les Lyciens et Termessos près d' Oinoanda (Fouilles de Xanthos X. Hautes études du monde gréco-romain 45), Geneva 2010. 
Solly 1875

Şahin 2014

Şahin - Adak 2007

Wallis - Chamberlain 1896

Yılmaz - Çevik 1996
N. N. Solly, Memoir of the Life of William James Müller, a Native of Bristol, Landscape and Figure Painter, with Original Letters, an Account of his Travels and his Principle Works, London 1875.

S. Şahin, Stadiasmus Patarensis. Itinera Romana Provinciae Lyciae, İstanbul 2014.

S. Şahin - M. Adak, Stadiasmus Patarensis. Itinera Romana Provinciae Lyciae, İstanbul 2007.

W. Wallis - A. B. Chamberlain (eds.), Catalogue of a loan collection of paintings in oil and water colours by William J. Muller, with descriptive notes and 24 illustrations, London 1896.

H. Yılmaz - N. Çevik, Tlos 1994, AST 13/1, 1996, 185-203.

\section{Helenistik Dönem Lykia’sının Kuzey Sınırlarında Masa Dağı \\ Öz}

1993 yılında Letoon'da bulunmuş olan bir yazıtta (Rousset 2010) ve J. Caesar ile Lykia Birliği arasındaki müttefiklik antlaşmasında (Mitchell 2005) Lykia'nın kuzey sınırlarında "Masa" adında bir dağın adı geçmektedir. İ. Ö. 160-150 arasına tarihlenen bu Letoon yazıtında söz konusu dağ Oinoanda'daki Termessoslular ve Lykialılar arasındaki bir sınır anlaşmazlığına konu olmaktadır. Bu sınır tartışması Kos kentinde görülen bir dava neticesinde çözüme ulaşmış ve taraflar Masa Dağı'nın Tloslulara ait olması, Oinoanda'daki Termessosluların da dağın sadece kereste ve otlaklarını kullanmaları ve de herhangi bir şekilde ekim dikim ya da inşa yapmamaları hususlarında anlaşmışlardır. Bunlar neticesinde Lykia Birliği Oinoanda'daki Termessoslulara 25 talanton yeni Rhodos gümüş plintofor'u ödemiştir. Bu anlaşma çerçevesinde Masa Dağı'nın detaylı bir şekilde sınırlandırılması yapılmış ve sınırlandırma komisyonunun tüm sınırlama faaliyeti yazıtta verilmiştir. Anakaya üzerine işlenen 18 adet sınır işaretinin yanı sıra, yollar, vadiler, akarsular, bir dağ geçidi, yaylalar, taşlık alanlar gibi pek çok coğrafi tanımlamalar da kullanılarak dağ etrafının kapsamlı bir resmi sunulmuştur. Bununla birlikte, bu kadar detaya rağmen dağın yeri bugüne kadar tespit edilememişti. 2019 yılındaki arazi çalışmalarımız neticesinde yazıtta bahsi geçen vadiler tespit edilerek, yazıtta anılan akarsulardan Golbanounda'nın Bayırköy’ün güneydoğusundaki Hacıosman Deresi, Endyrenos'un da Gökbel Yaylası'nın doğusundaki Sarısu olduğu gözlemlenmiş ve Masa Dağı'nın günümüzde Hacıosman Dağı olduğu anlaşılmıştır. Bu makale bu keşfin detaylarını içermektedir.

Anahtar Sözcükler: Masa Dağı, Hacıosman Dağı, Tlos, Termessos, Oinoanda, Lykia Birliği, sınır işaretleri, Letoon.

\section{The Location of Mount Masa on the Northern Border of Hellenistic Lycia}

\section{Abstract}

A mount called Masa is mentioned in an inscription from the Letoon (Rousset 2010) and in the foedus (treaty) between Caesar and Lycia (Mitchell 2005), as northern border of Hellenistic Lycia. The inscription from the Letoon, which dates from sometime 160-150 B.C., reads that this mount has been the subject matter of a border conflict between Termessans at Oinoanda and Lycians. This conflict was resolved in a case tried in Kos and parties accepted that Mount Masa should belong to Tloans, but Termessans at Oinoanda could use its wood and grass being prohibited to sow, to harvest or to build on its lands. In the sequel, Lycians had to pay 25 talents of new Rhodian silver plinthophors to Termessans at Oinoanda. Within the frame of this agreement, Mount Masa was demarcated all around and all the details of demarcation fulfilled by a commission were given 
in the inscription. In addition to 18 boundary marks carved on bedrock, through several geographic descriptions such as roads, ravines, streams, defiles, plateaux and stony places, a comprehensive picture around the mount was presented. However, the location of the mount was not found, in spite of all the details given in the text. As a result of our 2019 campaign, the ravines are determined on the field and it is understood that Golbanounda, one of two streams mentioned in the inscription, was today's Haciosman Deresi, and the second, Endyrenos, was today's Sarı Dere, to the east of Gökbel Yaylası. Therefore, it has now been understood that Mount Masa was Hacısman Dağı of today. This contribution contains the details of this discovery.

Keywords: Mount Masa, Mount Haciosman, Tlos, Termessos, Oinoanda, Lycian Confederacy, boundary marks, Letoon.

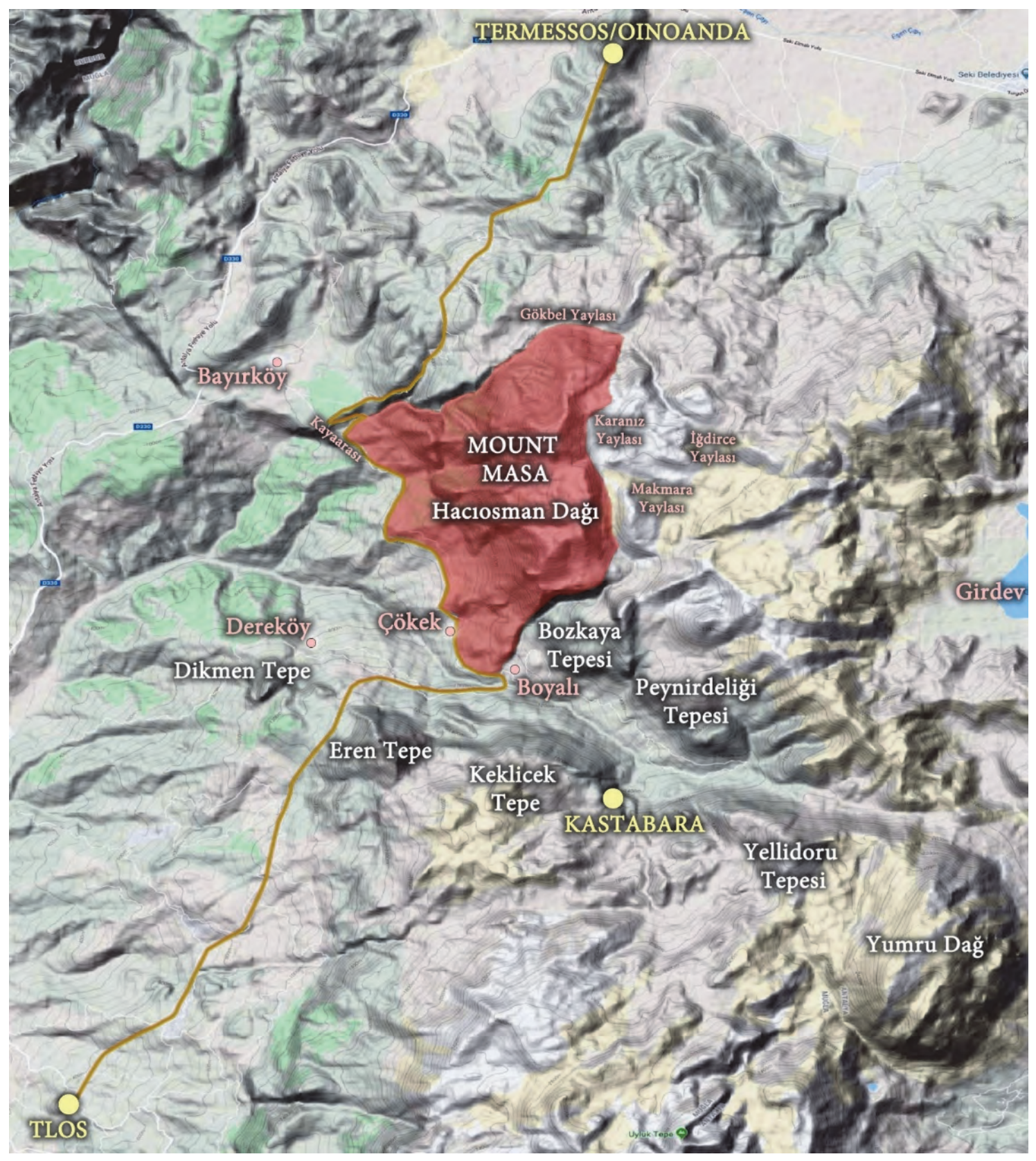

Fig. 36) Mount Masa between Tlos and Termessos at Oinoanda and the demarcated area (Base map: Google Terrain) 


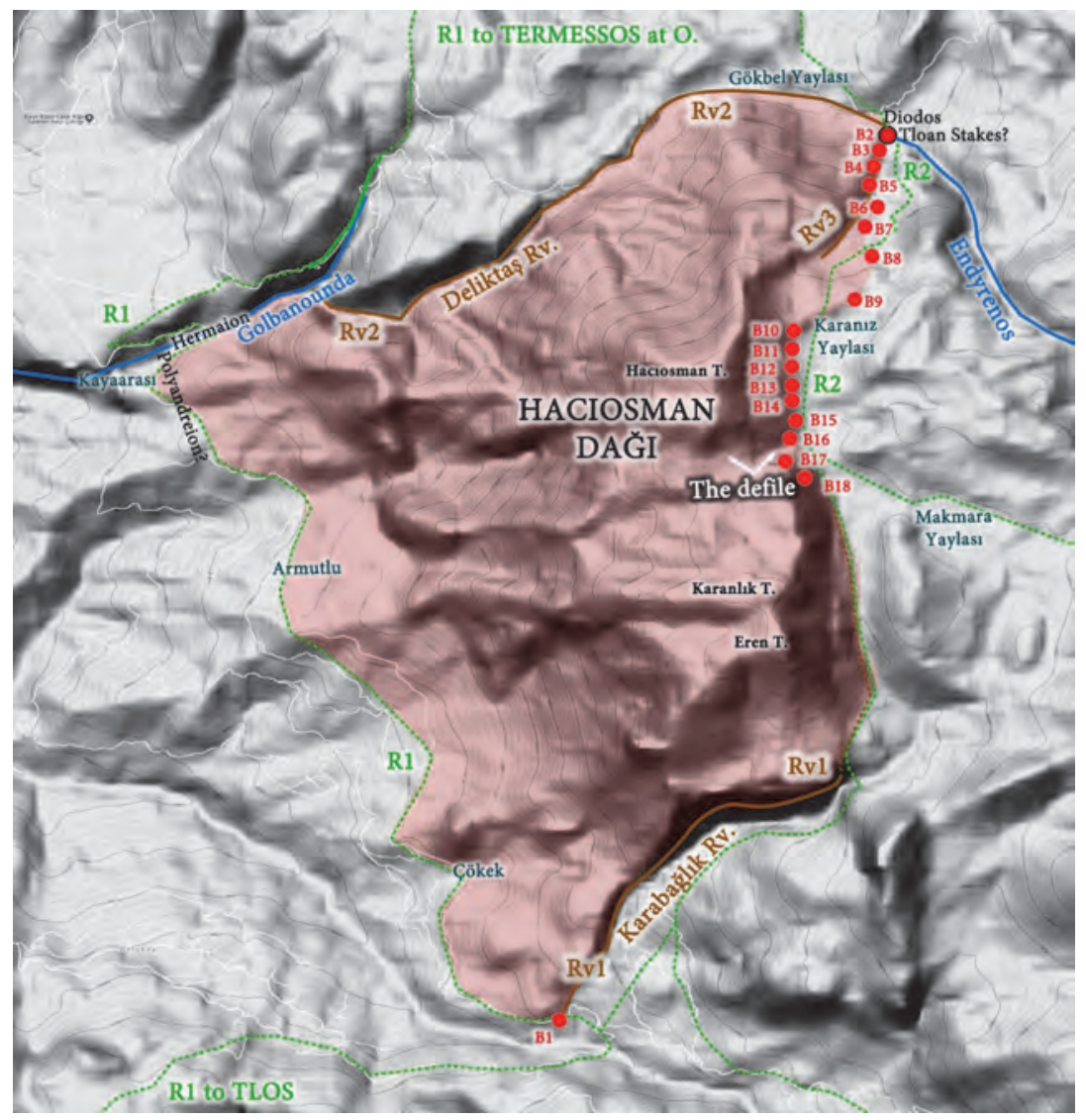

Fig. 37) The details of demarcation around Mount Masa in accordance with the text (Base map: Google Terrain)

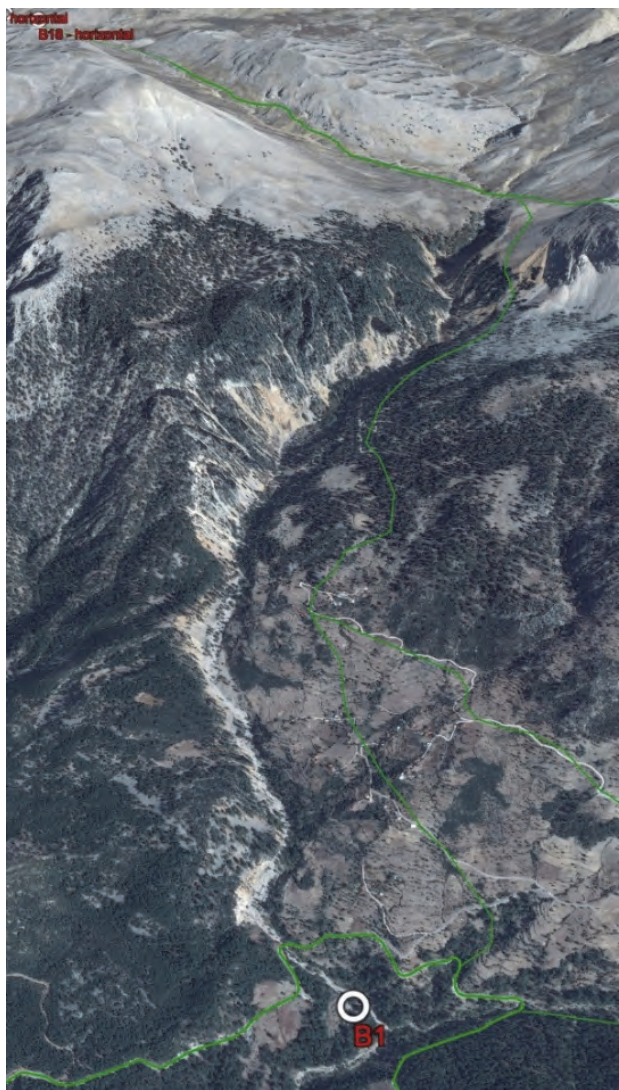

Fig. 38) Rv1: Karabağlık Ravine (Google Earth)

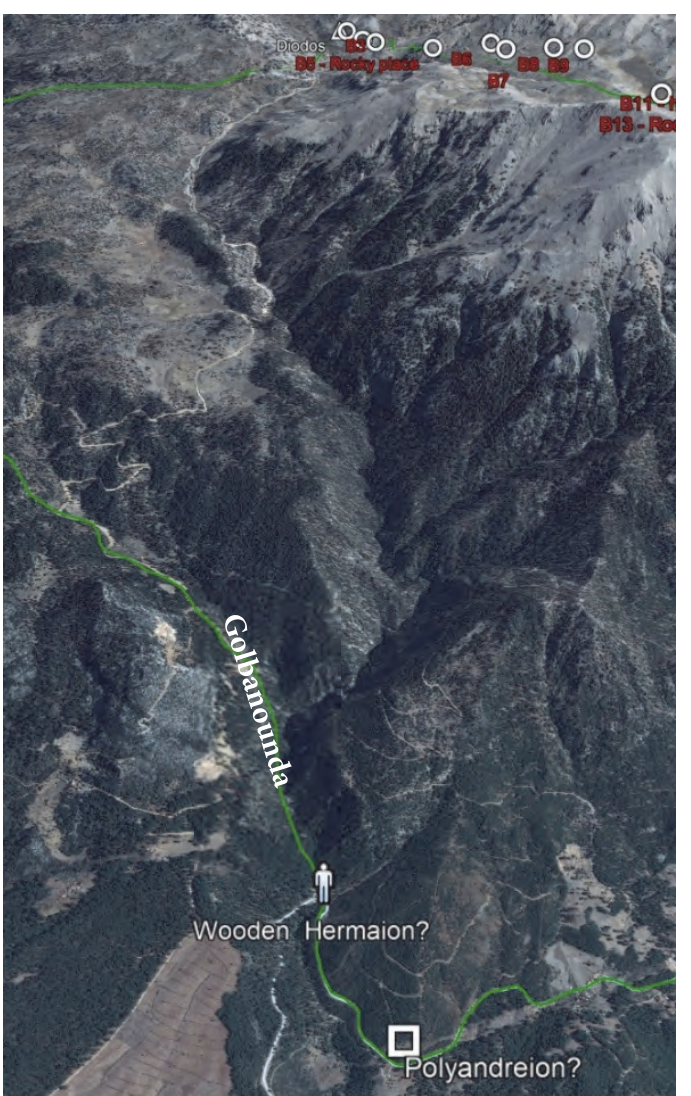

Fig. 39) Rv2: Deliktaş Ravine (Google Earth) 


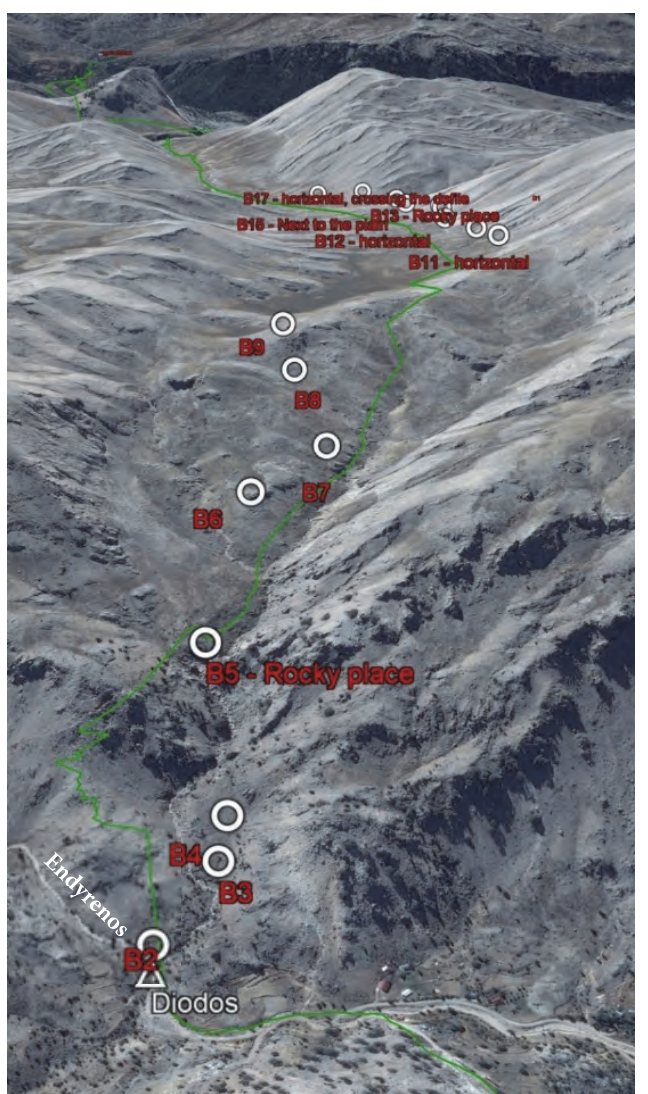

Fig. 40) Rv3. View to the south (Google Earth)

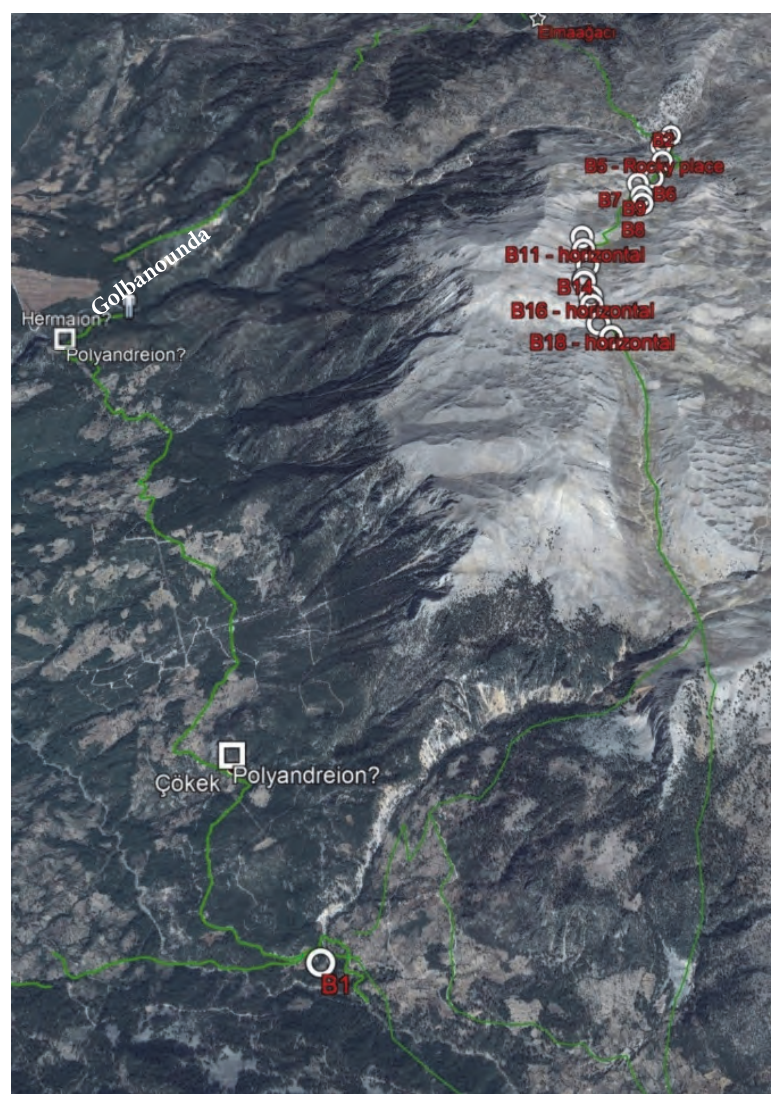

Fig. 41) View to the North (Google Earth)

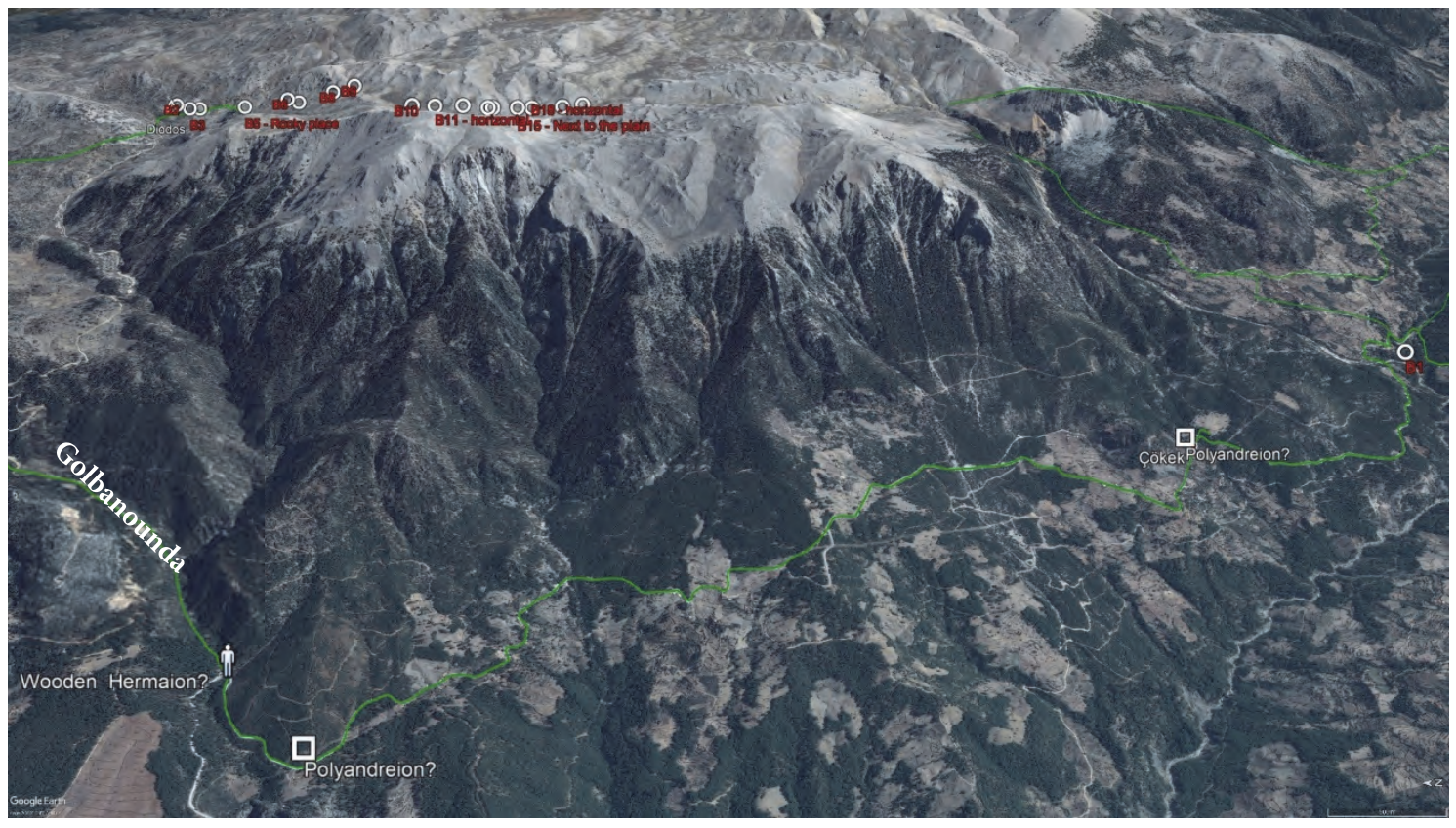

Fig. 42) View to east (Google Earth) 


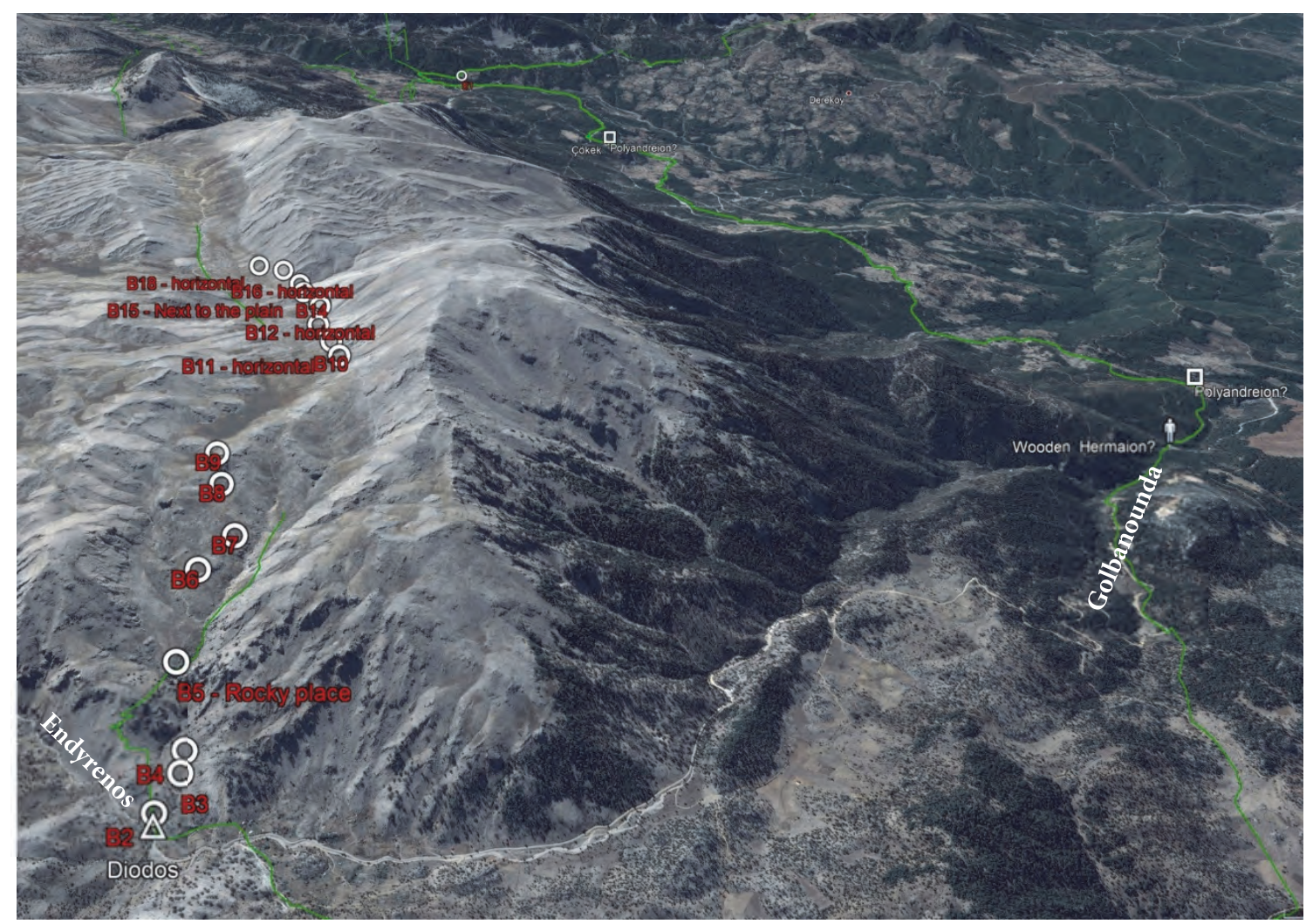

Fig. 43) View to the south (Google Earth)

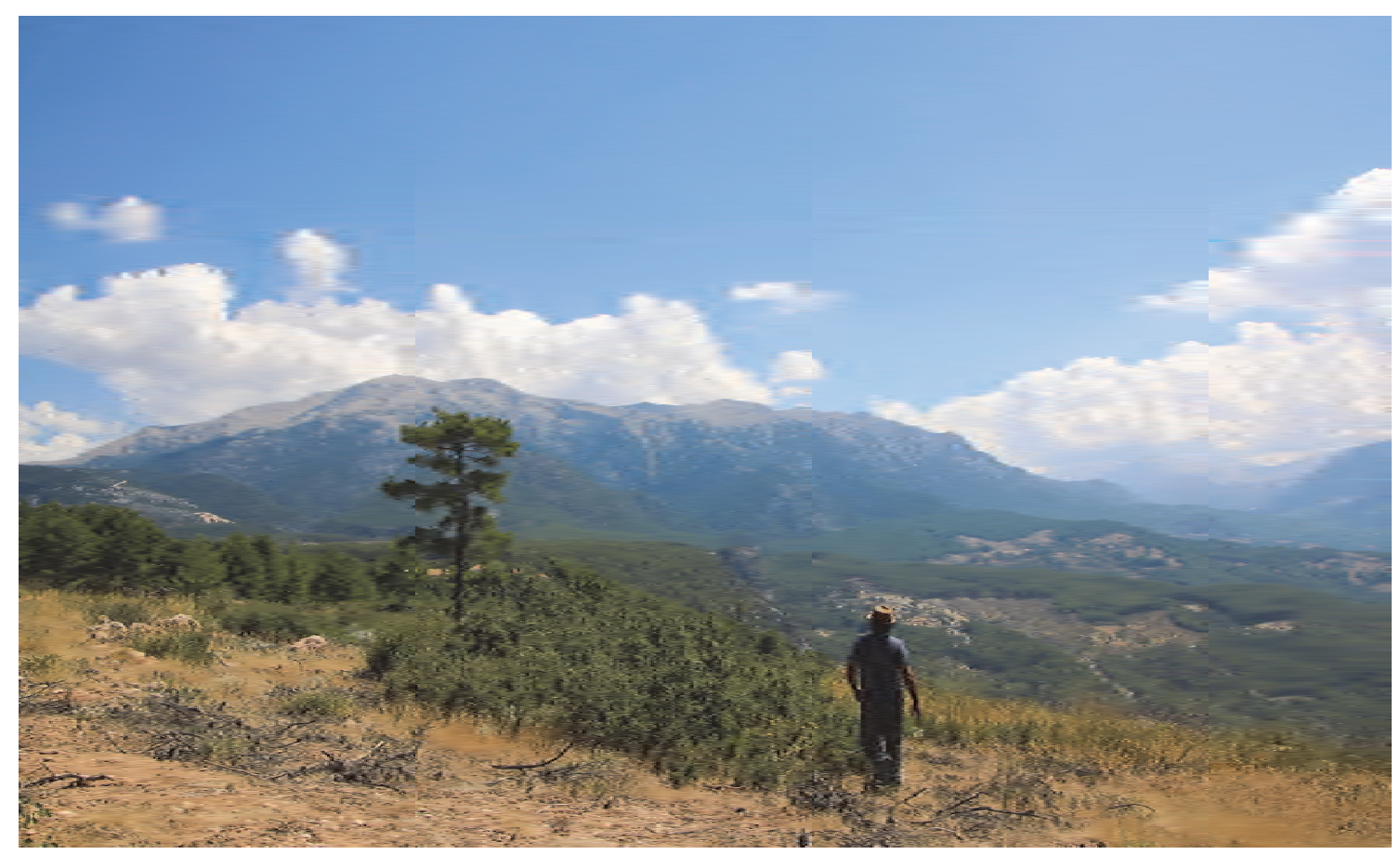

Fig. 44) Photograph taken by Fatma Avcu, September $5^{\text {th }} 2016$, Bayırköy, as our team was investigating the course of the road between Tlos and Oinoanda. View to the east. I am looking towards Hacıosman Dağ 1 